\title{
Lava flow crises in inhabited areas part l: lessons learned and research gaps related to effusive, basaltic eruptions
}

\author{
Sophia W. R. Tsang *i] and Jan M. Lindsay (B)
}

\begin{abstract}
Lava flows have threatened and/or inundated inhabited areas and/or their supporting networks 38 times at 12 volcanoes in the past 70 years. A systematic evaluation of these events has not been undertaken, making it hard to compare eruptions, create lava flow vulnerability models to support impact assessments, and deduce best practices for managing lava flow crises. In this paper, we summarise all 38 basaltic lava flow crises and conduct a gap analysis by evaluating published literature. Eleven data types that could support enhanced physical impact studies and/or research on the societal effects of lava flows were identified. Four of the data types (preparation actions and narrative, eruption narrative, response narrative, and evacuation data) have been well-documented (i.e. documented in at least half the eruptions). Communication approaches and recovery narratives have been included in at least a quarter of the studied eruptions, and their documentation in the literature is increasing with time. Five data types (lava flow attribute data, detailed physical impact data, and information on lava flow hazard modelling, community reactions, and applications of learnings) have only been documented a handful of times each. We suggest that standardisation of data collection and data storage could increase the frequency with which these data types are documented. Finally, we use the case studies to extract lessons about how community understanding of volcanic hazards influences community resilience and how lava flow modelling can inform planning. We also describe lessons relating to evacuation processes, mitigation methods, and recovery.
\end{abstract}

Keywords: Volcanic hazard, Case studies, Lava flow inundation, Effusive eruption, Lava flow damage

\section{Introduction}

Although infrequent, lava flow inundation of inhabited areas can have devastating consequences for affected communities. Lava flows bury assets and land in addition to bulldozing or igniting structures (e.g. Blong 1984; Oppenheimer 2011; Harris 2015; Kilburn 2015). While the resulting damage is frequently total, recent research (Tsang 2019a, 2019b) and recent eruptions suggest that lava flows can also cause progressive, complex impacts. For example some lava flow damage may depend on the properties of the flow; in the case of buried infrastructure, such as electric cables or water pipes, the

*Correspondence: s.tsang@auckland.ac.nz

School of Environment, University of Auckland, Auckland, New Zealand impact depends on the thickness and duration of the overriding flow as thermal impacts become progressively worse the longer the lava flow is active (Tsang 2019a, 2019b). Anecdotes from after the 1973 Vestmannaeyjar Volcanic Field eruption on Heimaey Island (Iceland) suggest that some structures with which lava flows come into contact can still be used after the eruption (Williams and Moore 1983); this can also be seen in the partial damage to buildings and infrastructure on the flanks of Mt. Etna in Sicily (Italy).

Although lava flows have impacted, threatened, and/or inundated settlements repeatedly over the past 70 years, there has been little analysis of the similarities and differences of how lava flows have impacted communities 
at different volcanoes. Most cross-volcano comparisons have been made as observations by scientists who work on several volcanoes (e.g. Global Volcanism Program 2019b). Since so few comparisons have been made, it can be difficult to assess what is well known about lava flow impacts and what could benefit from more data. Additionally, lessons learned from each eruption can be hard to generalise. Most anecdotes of lava flow inundations come from newspapers (e.g. Devries n.d..; Callis and Brestovansky 2018 May 18; Hawaii News Now 2018 October 3), rather than journal articles containing narratives about lava flow inundations (e.g. Jenkins et al. 2017). Although reports of previous lava flow inundations contain a wealth of information about how to prepare for, respond to, and recover from such events, a collation of such events has yet to be undertaken. Analysing available narratives not only helps areas facing inundation in the future but could also serve as the basis of vulnerability modelling (Jenkins et al. 2014; Wilson et al. 2014, 2017).

In this paper, we present a collation of events in which a lava flow has threatened or inundated an inhabited area. Although most of the events focus on a town(s), lava flows have also threatened and impacted inhabited areas indirectly by inundating supporting infrastructure network(s). We start with a short discussion on the events in the scope of our review, summarise these inundation case studies by volcano, and then identify outstanding research gaps. Finally, we use reoccurring themes across eruptions to describe lessons learned from lava flow crises.

\section{Scope of our review}

When compiling this review, we were especially interested in case studies that could support lava flow hazard and impact research. Thus, we developed two criteria to determine which lava flow events were in scope for our review.

1. We limited our scope to include only events that have threatened or inundated inhabited areas or their supporting networks since 1950, in order to maximise the chance that lessons learned are still applicable. Although people have been living on or near volcanoes that erupt effusively for millennia (e.g. the city of Naples surrounding Mt. Vesuvius), not all lessons from past lava flow inundations can be directly applied to modern cities for a variety of reasons, including advancements in technology and building codes. The rebuilding of Europe and Asia after World War II, the global trend of rapid urbanisation (Chester et al. 2001), and creation of new infrastructure networks (Tarr 1984) over the past 70 years has had significant impact on today's built environment, and many of these structures are still in service today.

2. We limited our review to basaltic lava flows, given that flows of this composition cause most inundations. The Smithsonian Institute's Global Volcanism Program's (https://volcano.si.edu/) rock types were used to determine if a volcano qualified for inclusion. This criterium ensures that if chemical reactions are important (e.g. reactions between bitumen roads and lava flows), then a smaller range of chemistries are being considered.

These two criteria ensure that the data gathered can be applied to future basaltic eruptions in urban areas built to building codes written after World War II, and that the amount of data gathered remained manageable.

\section{Methods}

Our methods can be divided into two steps: a literature review and a gap analysis. We first conducted an extensive literature review to collate formally and informally published data and accounts of basaltic lava flows that have threatened or impacted settlements or their supporting networks since 1950 . We started by querying the Smithsonian Institute's Global Volcanism Program database to develop a list of volcanoes that had produced basaltic eruptions since 1950. This list informed our literature search, which was conducted in English. All references were catalogued by volcano.

Subsequently a gap analysis was conducted on the literature review results. First, all the case studies were summarised (Section 3). Then, we developed a list of data types that would be useful to compare across case studies (Section 4). After, our literature review results were analysed to determine the extent to which the identified data types have been collected and published. This enabled us to identify gaps, which are described in Section 5. Finally, data in each data type were compared to extract lessons from the literature. When different actions were taken to address similar circumstances and one action had better outcomes than the other action, the positive action was considered a preferable practice, and therefore, lesson. Lessons learned are detailed in Section 6.2.

\section{Literature review: lava flow crises}

Thirty-eight lava flow events from 12 volcanoes fit the criteria in Section 1.1 (Fig. 1). Some eruptions were reported on by the media and written about extensively in the literature; these are described first. In each case, an overview of the eruptions at the volcano is presented, with contextual background information provided if needed. For our summary of each eruption we also tabulate information on any lava flow impacts, response actions, and any recovery efforts and subsequent application of lessons learned 


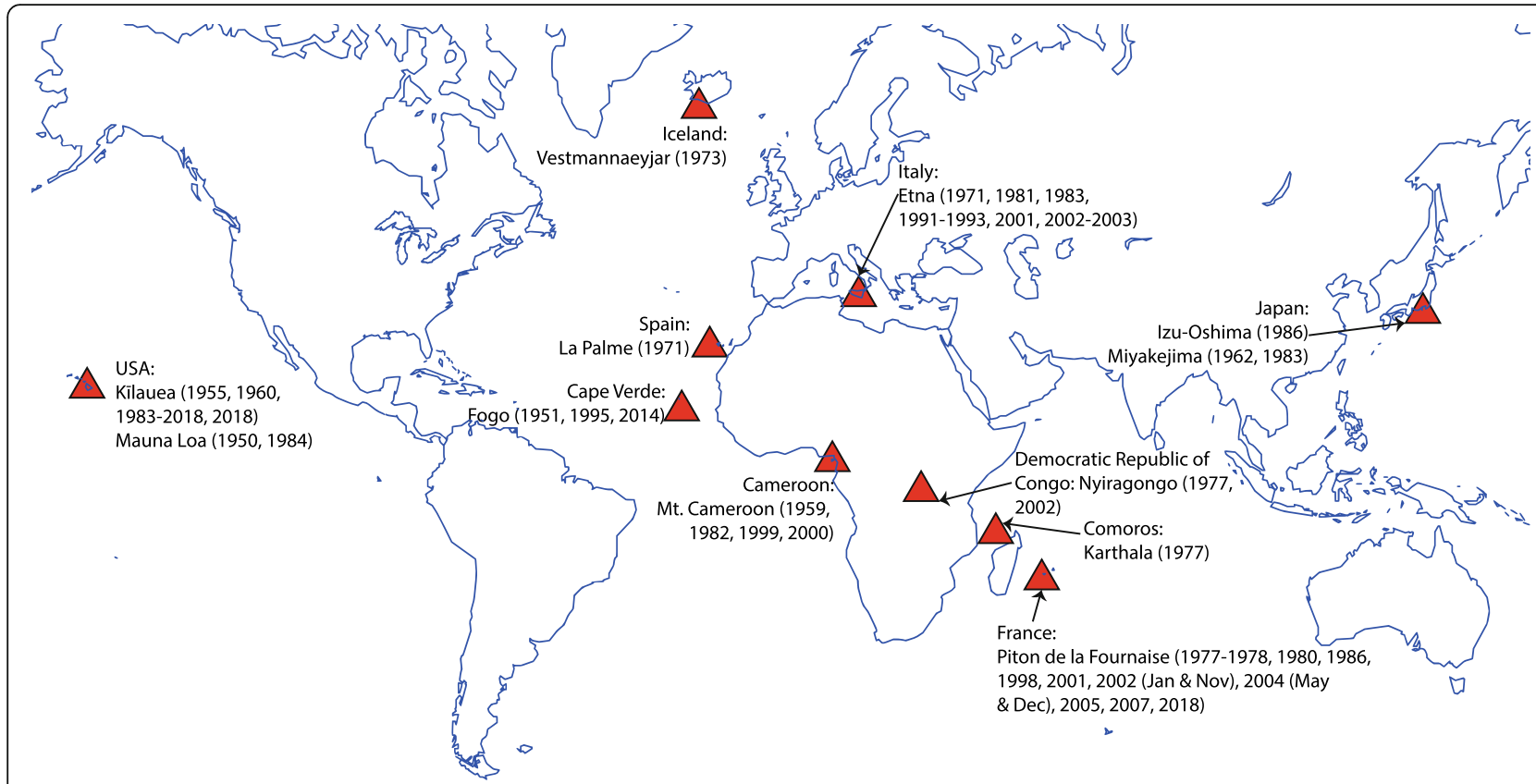

Fig. 1 World map indicating basaltic volcanoes that have erupted effusively since 1950 and affected the surrounding communities. Background map from Pixabay

in each summary table below. If information on any of these four topics is not tabulated for a given case study, it means it was not encountered in our literature review. In some cases, lessons from previous eruptions have not been codified via plans, but rather, have been applied based on individuals' experiences (i.e. stored via institutional memory). In such cases, these less tangible lessons are not included in the tables. Detailed data about an aspect of some eruptions that could support further lava flow impact studies have been included in Electronic Supplemental Material A.

\section{Etna, Sicily, Italy}

Etna is Europe's most active volcano and one of the most populated volcanoes in the world (Cappello et al. 2011; D'Ambrosio et al. 2013) and is extensively monitored. Most of Etna's basaltic lava flows are 'a'ā in character, although some flows exhibit pāhoehoe structures near the vent (Calvari et al. 1994; Avolio et al. 2006). Etnean lava flows can be grouped based on their duration, which greatly affects the length of the flow (Frazzetta and Romano 1984; Wadge et al. 1994). Short-duration lava flows are the most common (Behncke and Neri 2003; Branca and Del Carlo 2005) and extend up to $4 \mathrm{~km}$ from the source but can threaten the tourist facilities on Etna's flanks (e.g. Barberi et al. 2003; Coltelli et al. 2007; Bonaccorso et al. 2016). Longer lava flows extend over $10 \mathrm{~km}$ from the source and occasionally threaten the communities on Etna's lower flanks and around its base (Branca et al. 2017). Since 1950, five flank eruption lava flows have threatened and surrounded local buildings, farms, roads, and train tracks (Table 1).

Since communities around Etna are threatened by lava flows relatively frequently, Sicilians are famous for their lava flow mitigation attempts (Fig. 2; Table 1); recorded accounts stretch back to 1669 when Etnaen lavas invaded the city of Catania (e.g. Blong 1984; Crisci et al. 2003; Branca et al. 2015). In 1669, villagers attempted to divert the lava by breaking the side of the lava tube to let lava flow out and, thus, redirect it. A battle ensued by the flow margin between two villages that wanted to divert the flow in different directions. The conflict led to lava flow redirection and mitigation measures being outlawed for over 300 years (Huntington 1972), until an eruption in 1983 sparked public insistence that diversionary measures be undertaken (Table 1). In response to the public demand, a series of earthen barriers (Fig. 2) were created to slow the advance of the flow front while a redirection channel could be built up flow (Schanche 1983). Explosives were then inserted into the lava flow's levees to allow the lava to flow into the redirection channel instead of the natural channel (Abersten 1984). Subsequent lava flow redirection and mitigation attempts (e.g. Barberi et al. 1993; Bonaccorso et al. 2003; Chester et al. 2001, 2012) are summarised in Table 1.

\section{Kïlauea, Hawai'i Island, USA}

Kilauea is a shield volcano located on the Island of Hawai' $i$ and is also well monitored. It is a narrow volcano that has formed along two rift zones. A large portion of Kilauea's summit is part of the Hawaii Volcanoes 
Table 1 Table summarising information from reports of basaltic lava flow events at Mt. Etna that have threatened inhabited areas since 1950

\begin{tabular}{|c|c|c|c|}
\hline Eruption (references) & $\begin{array}{l}\text { Overview, including impacts } \\
\text { (eruption duration) }\end{array}$ & Response & Recovery \& Applying lessons learned \\
\hline $1971(1,2,3)$ & $\begin{array}{l}\text { Two lava flows emerged from } \\
\text { a vent at } 3000 \mathrm{~m} \text { asl on Etna's } \\
\text { southern flank. Flows destroyed } \\
\text { the volcano observatory, cable }\end{array}$ & $\begin{array}{l}\text { Parallel practice was common, } \\
\text { i.e. increased religious practice in } \\
\text { conjunction with practical } \\
\text { measures such as preparing }\end{array}$ & $\begin{array}{l}\text { Huntington 1972) An lamented that } \\
\text { nothing could be done because } \\
\text { it was illegal to alter the course } \\
\text { of a lava flow. }\end{array}$ \\
\hline
\end{tabular}
car network, agricultural land, $350 \mathrm{~m}$ of road, and bridges and ignited forest fires. Tourist facilities and two towns on the southeastern flank were threatened but not inundated. (9.5 weeks)

$1981(4,20,21)$

$1983(5,6,22,24)$

1991-1993 (7, 8, 9, 10, 20)

$2001(11,12,13,15,18,17,19,20) \quad$ Fissures on Etna's SE cone produced seven vents, four of which effused lava flows that eventually threatened tourist facilities and two villages. A local highway was inundated within $24 \mathrm{~h}$ of the eruption onset. Within two weeks, ski lines and part of the tourist facilities' car parks had also been inundated. (3.5 weeks)
Parallel practice was observed again.

Public pressure led to government approval to attempt a lava flow redirection project. An international explosives expert was contracted to create a hole in the lava tube. The hole did not divert a significant portion of the flow and self-healed quickly.

Lava flow modelling was carried out within the first week of the eruption and indicated that the town Zafferana Etnea could eventually be inundated. US military were asked to assist by dropping objects into a skylight in the lava tube. Earthen barriers were built to slow the flow's advance (Fig. 2). Diversion channels were used to redirect the flow. Eventually, the entire lava flow was successfully diverted into the artificial lava channel that had been dug to redirect the lava flow.

A preliminary version of DOWNFLOW was used to model the lava flows during this eruption; the resulting maps were shared on the news (S. Tarquini, pers. comm.) Tourist facilities and a monitoring station were closed. Thirteen earthen barriers and a diversion project (similar to the 1991-1993 eruption) were implemented. Some structures were saved. A detailed evacuation plan was also drafted although not enacted.

DOWNFLOW lava flow modelling
Numerical software packages were developed and calibrated to predict Etnean lava flow footprints. The science teams that implemented the diversion barriers and channels in each of these eruptions were composed of many of the same people who maintained institutional knowledge of actions during previous eruptions.
Post-eruption lava flow modelling was undertaken to analyse how well the earthen barriers performed (i.e. examine if the barriers were built in optimal orientations). 
Table 1 Table summarising information from reports of basaltic lava flow events at Mt. Etna that have threatened inhabited areas since 1950 (Continued)

\begin{tabular}{|c|c|c|c|}
\hline Eruption (references) & $\begin{array}{l}\text { Overview, including impacts } \\
\text { (eruption duration) }\end{array}$ & Response & Recovery \& Applying lessons learned \\
\hline & $\begin{array}{l}\text { both the northeastern and } \\
\text { southeastern rifts. A vent at } \\
2500 \mathrm{~m} \text { on Etna's southeastern } \\
\text { flank created a lava flow that } \\
\text { advanced } 1 \mathrm{~km} \text {. A second vent } \\
\text { at } 2200 \mathrm{~m} \text { effused a lava flow } \\
\text { that inundated tourist facilities } \\
\text { and two roads and ignited forest } \\
\text { fires. A month later, a third lava } \\
\text { flow again threatened the tourist } \\
\text { facilities. A final lava flow inundated } \\
\text { a government building three } \\
\text { months after the eruption onset. } \\
\text { ( } 3 \text { months) }\end{array}$ & $\begin{array}{l}\text { was undertaken to determine } \\
\text { potential inundation sites. Six } \\
\text { earthen barriers were constructed. } \\
\text { The flow front did not reach the } \\
\text { barrier on the northern flank, } \\
\text { which was subsequently removed. } \\
\text { The barriers on the southern flank } \\
\text { successfully protected the tourist } \\
\text { facilities. }\end{array}$ & $\begin{array}{l}\text { monitoring methods have been } \\
\text { implemented including } \\
\text { augmenting ground-based } \\
\text { networks and improving remote } \\
\text { sensing techniques. }\end{array}$ \\
\hline
\end{tabular}

1: Huntington (1972), 2: Walker (1973), 3: Guest et al. (1980), 4: Science News (1981 March 28), 5: Schanche (1983), 6: Abersten (1984), 7: Bompard and Philips (1992 April), 8: Barberi et al. (1992), 9: Barberi et al. (1993), 10: Wadge et al. (1994), 11: News Service Reports (2001 July 29) 12: Reuters (2001 July 31), 13: Reuters (2001 August 1), 14: Villa (2002), 15: Barberi et al. (2003), 16: Andronico et al. (2005), 17: Favalli et al. (2005), 18: Coltelli et al. (2007), 19: Scifoni et al. (2010), 20: Cappello et al. (2011), 21: Coltelli et al. (2012), 21: Bonaccorso et al. (2016), 22: Rongo et al. (2016), 23: Tarquini and Favalli (2016), 24: Carapezza (2017)

National Park, but people have also built communities on the shallow slopes between its East Rift Zone and the ocean, an area at high risk of lava flow inundation (Wright et al. 1992). The largest community on Kîlauea's eastern flank is Pāhoa, a town of 945 people (US Census 2010), which also serves as the "gateway" to communities south of it as it is the only access route (Tsang 2019b). Killauea has erupted multiple times since 1950, including continuously between 1983 and 2018 (Table 2). It produces basaltic lava flows that frequently reach the sea and thus contribute to the growth of the island (e.g. Macdonald 1958; Chirico et al. 2009;
Poland et al. 2015; Neal et al. 2019; Table 2). Both 'a'ā and pāhoehoe flows can be found on Kìlauea although the most two recent effusive eruptions to threaten communities have both been primarily pāhoehoe in style (Neal et al. 2019; Brantley et al. 2019).

Physical mitigation strategies have been considered on multiple occasions on Killauea. In 1881, Hawaiian communities discussed erecting a physical barrier to protect the built environment from being overrun by lava (Chirico et al. 2009). No wall was built since the native $\mathrm{Ha}$ waiians strongly believe that lava is the embodiment of Pele, the Hawaiian goddess of volcanoes, and that Pele's

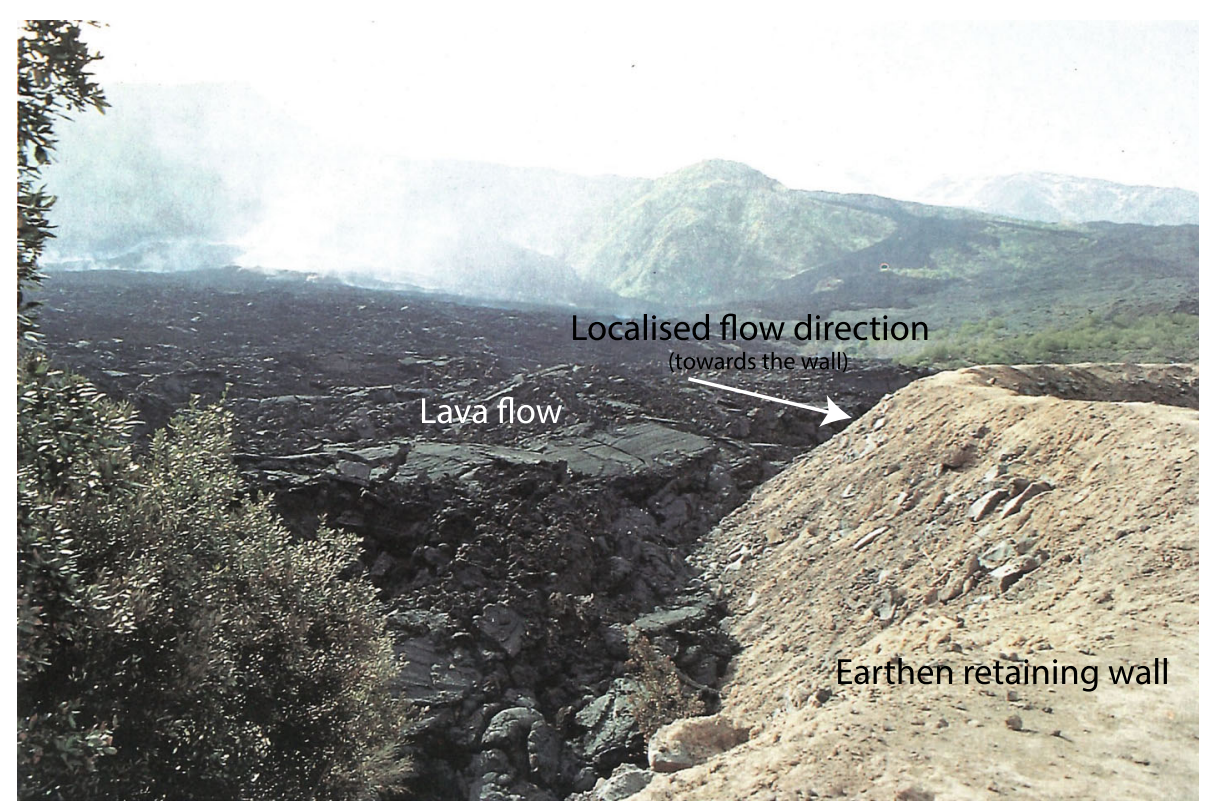

Fig. 2 Lava flow from the 1991-1993 eruption of Etna stalling behind an earthen barrier while an artificial channel is built downhill. Image modified from Barberi et al. (1993) 
Table 2 Table summarising lava flow events at Kilauea Volcano that have threatened inhabited areas since 1950

\begin{tabular}{|c|c|c|c|}
\hline Eruption (References) & $\begin{array}{l}\text { Overview, including impacts } \\
\text { (Eruption duration) }\end{array}$ & Response & Recovery \& Applying lessons learned \\
\hline $1955(7)$ & $\begin{array}{l}\text { After a rapid increase in local seismicity, } \\
\text { lava began effusing out of new fissures } \\
\text { on Kilauea's Lower East Rift Zone (LERZ). } \\
\text { Within the first week, fissures had } \\
\text { opened in Kapoho township, feeding } \\
\text { lava flows and destroying several } \\
\text { houses and cutting off all access. } \\
\text { During the second month of the } \\
\text { eruption, fissures continued opening } \\
\text { en echelon up the LERZ, creating more } \\
\text { lava flows and destroying roads and } \\
\text { agricultural land. A cinder cone and }\end{array}$ & $\begin{array}{l}\text { The formation of fissures close to } \\
\text { Kapoho township led to the township } \\
\text { (i.e., people and their belongings) being } \\
\text { evacuated. During the second month of } \\
\text { the eruption, all residents south of the } \\
\text { fissures were evacuated. Contingencies } \\
\text { were planned in case the shelters were } \\
\text { threatened. Two retention walls were } \\
\text { built to protect agricultural land but } \\
\text { overtopped. The walls were } \\
\text { supplemented with dikes, which } \\
\text { delayed the destruction of the land. }\end{array}$ & $\begin{array}{l}\text { Within a week of the end of the active } \\
\text { lava, roads had been bulldozed across } \\
\text { the lava flows to allow evacuees to } \\
\text { return with the plan that the church } \\
\text { bell would be rung if another } \\
\text { evacuation was necessary. Lots of } \\
\text { knowledge about responding to lava } \\
\text { flows in a US context was gained } \\
\text { during this eruption (and subsequently } \\
\text { used in other eruptions) as this was } \\
\text { the first eruption in a populated } \\
\text { area in Hawaii since its statehood. }\end{array}$ \\
\hline
\end{tabular}

$1960(1,2,3) \quad$ This eruption began with fire-fountaining approximately half a kilometre outside of Kapoho. Within a day, 'a'ā flows began advancing northeast, towards agricultural land. Within two days, the flows reached the ocean, forming new land. (1 month)

1983-2018 (4, 5, 6, 8, 9) 1983-1990: Pu'u'Ō'ō, a new cinder cone, grew on Kïlauea's East Rift zone, commencing an eruption that would last 35 years. During the beginning of the eruption, lava flows inundated the neighbourhood east of the cone. Later, breakouts in a lava tube allowed flows to advance south and progressively inundate the town of Kalapana, which consisted of approximately 100 houses, a church, and a store.

2007: Lava flows began advancing towards downslope towns although never reached

them.

2014-2015: Lava flows advanced towards Pāhoa township, causing a series of response measures. A single building was fully destroyed; a second was partially inundated. A road was traversed. The electricity transmission line running along the road maintained service. (35 years)

$2018(10,11)$

Twenty-four fissures opened and firefountained in the LERZ. Two fissures created flow fields and ocean entries. Several subdivisions were partially to fully destroyed. (3 months)
The formation of ground cracks prior to the eruption onset prompted many residents to self-evacuate. Again, retaining walls were built and overtopped by lava although protected some structures. Kapoho evacuated, and some buildings were moved.

1983-1990: Families evacuated, and the local church was moved. 2007: Lines of steepest descent were updated. Hawaiian cultural practitioners were asked to intervene. 2014-2015: Residents self-evacuated. Evacuation routes were built. The electricity company designed and built structures to protect power poles. Only one power pole was surrounded by the lava flow; it caught on fire. Service was preserved by disconnecting the wire from the pole before it was destroyed. Community meetings were held weekly, and some community member perspectives were documented in social science resilience studies.

Most response efforts focused on modelling areas that could be inundated, evacuating the area, and maintaining the resulting exclusion zone.
Ten square kilometres were inundated, and $2 \mathrm{~km}^{2}$ of new land were formed. Kapoho was not rebuilt in the same location. Rather, families moved into other local subdivisions.

(1983-2017) By 2017, some families had moved back into the Kalapana area, building structures on top of the flows.

(2007) No physical damage reported. (2014-2015) Lava was removed from the road so that the road could be used. The power poles were replaced. The partially inundated building was remediated. The destroyed structure was turned into a tourist attraction. Local and state level emergency management plans were formulated to address lava flow crises. Local groups began holding more frequent preparedness workshops.

As of September 2019, the exclusion zone has been lifted. Some roads have been re-established, and residents are slowly returning.

1: Macdonald (1962), 2: Barberi et al. (1993), 3: Chirico et al. (2009), 4: Hawai'i Electric Light (2014a) 5: Hawai'i Electric Light (2014b), 6: Poland et al. (2015), 7: HVO (2018), 8: Brantley et al. (2019), 9: Ching et al., 2020, 10: Neal et al. (2019), 11: Dietterich et al. (2018)

movements should not be restricted (Herbert and Bardossi 1968). Thus, most response measures have focused on safely moving people and buildings out of the lava flows' paths although a few walls were built in the midtwentieth century.
Mauna Loa, Hawai'i, USA

Mauna Loa is one of the largest volcanoes in the world and has also contributed to the growth of Hawai'i Island. Similar to Kilauea, Mauna Loa has two rift zones: one to the northeast and one to the southwest. The town of Hilo 
is situated near the bottom of the northeastern rift zone while the Ocean View subdivision (one of the largest subdivisions in the United States) is situated on the southwestern rift zone. The majority of Mauna Loa's historical eruptions outside of its crater have been along one of the two rift zones (Wright et al. 1992). Mauna Loa has erupted three times since 1950 with the most recent eruption in 1984 (Global Volcanism Program 2019d; Table 3). Mauna Loa often produces 'a'à lava flows that travel on steep slopes, meaning they can advance quickly and have reached the ocean in less than three hours (Finch and MacDonald 1953; HVO 2016). Similar to Etna and Kilauea, Mauna Loa is well monitored.

Fewer mitigation actions have been undertaken at Mauna Loa although experiments have been proposed to protect settlements from lava flows. As early as the 1920s, several scientists suggested bombing the sides of lava flows to create holes in their tubes or levees (Macdonald 1958). This method was tested twice in 1935 and in 1942. Neither attempt was deemed a success although subsequent literature suggests that the conditions were not ideal (Macdonald 1958). In the late 1930s, Dr. Thomas Jaggar also suggested building walls to protect Hilo from Mauna Loa lava flows although this project never eventuated (Macdonald 1958). Even prior to the Italian experiments (see section 3.1), this method was considered to be more reliable given that walls (either protecting the city or of buildings) had previously withstood the temperatures and pressures of lava flows (e.g. 1669 eruption of Etna and Catania's city walls, 1906 and 1944 eruption of Vesuvius and buildings).

\section{Vestmannaeyjar, Heimaey, Iceland}

The Vestmannaeyjar Volcanic Field is located just south of the Icelandic mainland and consists primarily of submarine vents. Recently, it is well monitored by the Science Institute. In 1973, a new vent (named Eldfell) formed on the island of Heimaey, one of the islands created by the volcanic field (Table 4). The resulting lava flow field threatened and partially inundated the only town on the island, also named Vestmannaeyjar, which was renowned for its harbour. This eruption is especially notable because of the novel attempt at using water to divert lava flows away from the town's harbour and because of the town's recovery (Fig. 3). Although some buildings were permanently destroyed, others, including the fish factories shown Fig. 3, were repaired and utilitsed again after the eruption. This anecdote suggests that some lava flow damage is remedial (right image in Fig. 3). All residents who did not serve in a first responder capacity evacuated to the mainland during the eruption; following the end of the eruption, not everyone returned, but those who did returned relatively quickly (Williams and Moore 1983).

\section{Nyiragongo, Democratic Republic of Congo}

Nyiragongo is one of the most active volcanoes in Africa, situated $14 \mathrm{~km}$ from the city of Goma (Crane 2011). Although a monitoring network has been installed, less data is available due to issues relating to the security of the instrumentation (Finkel 2011). Since 1950, Nyiragongo has had two eruptions which produced lava flows that extended far beyond the summit (Table 5). Due to the lava's foiditic composition (Global Volcanism Program 2019f), lava flows in both eruptions travelled quickly enough to kill people (Tazieff 1977; Tazieff 1985; Favalli et al. 2006, Favalli et al. 2009a ; Haapala 2011; Morrison et al. 2020; Table 5). The lava flows in the 1977 eruption are still the fastest moving lava flows on record (Crane 2011). Due to the high lava flow hazard posed by Nyiragongo, several lava flow modelling studies have been undertaken to determine the areas at highest risk. Some of these studies have also led to potential planning measures to reduce the population's risk. For example, Fig. 4 displays DOWNFLOW lava flow

Table 3 Table summarising basaltic lava flow events at Mauna Loa Volcano that have threatened inhabited areas since 1950

\begin{tabular}{|c|c|c|c|}
\hline Eruption (References) & Overview, including impacts (Eruption duration) & Response & Recovery \& Applying lessons learned \\
\hline $1950(1,2,5,6)$ & $\begin{array}{l}\text { This three-week, central caldera and southwest rift } \\
\text { zone eruption had a rapid onset and created eight } \\
\text { lava flows. Three of the flows reached the ocean, } \\
\text { with one entering the sea within } 3 \mathrm{~h} \text {. Advancing at } \\
9 \mathrm{~km} / \mathrm{hr} \text {., the flows caused forest fires and inundated } \\
\text { roads (including the circum-island highway) and a } \\
\text { town. Other towns were threatened. There were no } \\
\text { casualties. The total volume of lava erupted was } \\
3.76 \times 10^{8} \mathrm{~m}^{3} \text {. ( } 3 \text { weeks) }\end{array}$ & $\begin{array}{l}\text { The rapid pace of this eruption } \\
\text { meant that response actions } \\
\text { focused on evacuating people. }\end{array}$ & Not reported on. \\
\hline $1984(3,4)$ & $\begin{array}{l}\text { Lava flows from the caldera and eastern rift zone } \\
\text { advanced towards the town of Hilo. The flow's } \\
\text { advancement slowed when reaching shallow slopes } \\
\text { and halted } 7 \mathrm{~km} \text { from town. ( } 3 \text { weeks) }\end{array}$ & $\begin{array}{l}\text { No mitigation was undertaken } \\
\text { although discussions were held } \\
\text { about circumstances that would } \\
\text { prompt such measures. }\end{array}$ & No physical damage to recover from. \\
\hline
\end{tabular}


Table 4 Table summarising basaltic lava flow events at Vestmannaeyjar Volcanic Field that have threatened inhabited areas since 1950

\begin{tabular}{|c|c|c|c|}
\hline Eruption & $\begin{array}{l}\text { Overview, including impacts } \\
\text { (Eruption duration) }\end{array}$ & Response & Recovery \& Applying lessons learned \\
\hline 1973 & $\begin{array}{l}\text { A new volcanic vent in the Vestmannaeyjar } \\
\text { Volcanic Field opened near the town of } \\
\text { Heimaey. The eruption fire-fountained, } \\
\text { creating tephra and lava flows. The lava } \\
\text { flow stopped advancing before inundating } \\
\text { the entire town and harbour. (5 months) }\end{array}$ & $\begin{array}{l}\text { Villagers evacuated the island along with } \\
\text { their belongings and livestock. The first } \\
\text { responders put out fires and tried to } \\
\text { protect the town's harbour using water } \\
\text { pumped from the harbour. Iceland } \\
\text { requested aid from other countries } \\
\text { to ensure enough equipment. }\end{array}$ & $\begin{array}{l}\text { Some of the town was rebuilt; other parts } \\
\text { were unburied and continue to be used. } \\
\text { Within a year, two of the town's fish factories } \\
\text { had been unburied and were in working } \\
\text { order again (Fig. 3). Additionally, the town } \\
\text { used the cooling lava flows to create energy } \\
\text { to power the town for over a decade. }\end{array}$ \\
\hline
\end{tabular}

Thorarinsson et al. (1973), Williams and Moore (1983), McPhee (1989)

modelling together with suggestions for barriers to protect areas of Goma, while allowing certain areas to be inundated without impacting the city.

\section{Piton de la Fournaise, La Réunion, France}

Piton de la Fournaise is one of the world's most active volcanoes, frequently producing lava flows although the majority of the eruptions occur wholly within the caldera (Davoine and Saint-Marc 2016; Staudacher et al. 2016). It is well monitored by the Piton de la Fournaise volcano observatory to protect the towns on the volcano's flanks. There are six major towns on Piton de la Fournaise's flanks, with none located in the large valley to the crater's east (Gillot and Nativel 1980). A major transportation route runs across the valley, though (Harris and Villeneuve 2018a). Since 1950, inhabited areas have been threatened or inundated in 11 eruptions (Table 6). Since lava flows frequently threaten towns on La Réunion, citizens are not averse to evacuating when necessary (Nave et al. 2016). There are no reports of any actions being undertaken to mitigate the potential impacts of lava flows nor reports describing inundated areas being used again (Global Volcanism Program 2019g; Table 6).

\section{Karthala, Grande Comore, Comoros}

Karthala is the southern volcano on Grande Comore, the largest island in the Comoros. It has two rift zones that extend to the north-northwest and the southeast (Bachelery et al. 2016). While it erupts frequently, most eruptions remain in the main crater (Chahale) where they do not threaten settlements. The only effusive eruption that has impacted settlements since 1950 occurred in 1977 (Table 7). The three affected settlements were all located in relatively low lava flow hazard zones (Bachelery et al. 2016). Since this eruption, a volcanic observatory has been built (Bachelery et al. 2016) although its monitoring networks frequently are pilfered by locals (e.g. Morin and Lavigne 2009; Morin et al. 2016). Although Karthala has affected settlements less frequently than other case studies presented here, Grande Comore has been the focus of multiple studies on lava flow hazard and community's understanding of it (e.g. Morin and Lavigne 2009; Morin et al. 2009; Mossoux et al. 2019).

\section{Fogo, Fogo, Cape Verde}

Fogo is the volcano on island of the same name, off the western coast of Africa. There are several villages and settlements built in its caldera with a total population that has grown from 1300 people to 1500 people between 1995 and 2014 (Komorowski et al. 2018). These settlements are agricultural, including a vineyard (Jenkins et al. 2014), so effusive eruptions can mean prolonged economic downturns as lava flows generally do not improve the agricultural value of land (Deligne 2012). Another 11,000 people live on Fogo's northeastern flank which is open to the caldera (Komorowski et al. 2018). Over the past 70 years, the settlements in
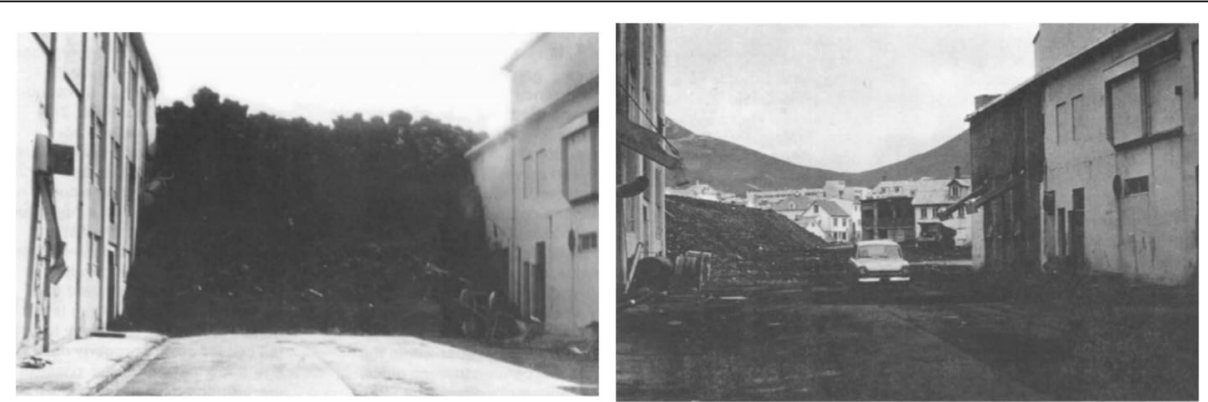

Fig. 3 Left image is of a lava flow between two factories in Vestmannaey during the 1973 Eldfell eruption. The image on the right was taken a year later from the same location after the lava flow had been removed and reconstruction of the factories had begun. Images courtesy of U.S. Geological Survey, from Williams and Moore (1983) 
Table 5 Table summarising basaltic lava flow events at Nyiragongo Volcano that have threatened inhabited areas since 1950

\begin{tabular}{|c|c|c|c|}
\hline $\begin{array}{l}\text { Eruption } \\
\text { (References) }\end{array}$ & $\begin{array}{l}\text { Overview, including impacts (Eruption } \\
\text { duration) }\end{array}$ & Response & $\begin{array}{l}\text { Recovery \& Preparation for subsequent } \\
\text { eruptions }\end{array}$ \\
\hline $1977(1,2)$ & $\begin{array}{l}\text { The lava lake suddenly drained and } \\
\text { reappeared through a fissure. ( } 1 \text { day) }\end{array}$ & $\begin{array}{l}\text { No response actions reported; this } \\
\text { sudden onset eruption was short-lived. }\end{array}$ & $\begin{array}{l}\text { A monitoring system was installed } \\
\text { but is not always functional. }\end{array}$ \\
\hline $2002(3,4,5,6,7)$ & $\begin{array}{l}\text { The lava lake suddenly drained and } \\
\text { reappeared through a fissure. The } \\
\text { resulting lava flow advanced through } \\
\text { the city of Goma. ( } 2.5 \text { weeks) }\end{array}$ & $\begin{array}{l}\text { There was little coordinated response } \\
\text { although residents self-evacuated. } \\
\text { International organisations (e.g. the } \\
\text { United Nations) set up refugee shelters } \\
\text { in Rwanda. }\end{array}$ & $\begin{array}{l}\text { Within a month, lava flows that traversed } \\
\text { roads already had new paths and/or roads } \\
\text { across them. Lava flow modelling was } \\
\text { conducted leading to the proposal of } \\
\text { mitigation measures (Fig. 4). This eruption } \\
\text { led to the development of volcanic } \\
\text { contingency plans in DRC and Rwanda } \\
\text { by international organisations. }\end{array}$ \\
\hline
\end{tabular}

1: Tazieff (1977), 2: Tazieff (1985), 3: Lacey (2002a Jaunary 21), 4: Lacey (2002b Janary 23), 5: Allard et al. (2003), 6: Giordano et al. (2007), 7: Finkel (2011)

the caldera have been threatened and/or inundated by lava flows in three eruptions (Table 8). The National Civil Protection Service, which is led by the local military, was established relatively recently, so it was only involved in the response to the 2014 eruption (Komorowski et al. 2018).

\section{Izu-Oshima, Oshima Island, Japan}

Oshima Island is the largest island in the Izu island group off the coast of Japan, south of Toyko. Oshima Island has been built by three volcanoes that began erupting in the Pliocene; the youngest volcano Izu-
Oshima is still active (Sumner 1998). Izu-Oshima's peak Mt. Mihara is slightly to the southwest of the centre of the island, which is home to approximately eight thousand people (Global Volcanism Program 2019c). Although there have been at least 20 eruptions at IzuOshima in the last 70 years, most have remained in the crater. Only one has created lava flows that have extended beyond the crater and, therefore, could potentially threaten local communities and/or structures (Global Volcanism Program 2019c; Table 9). Four seismic stations and two deformation stations are used to monitor Izu-Oshima.

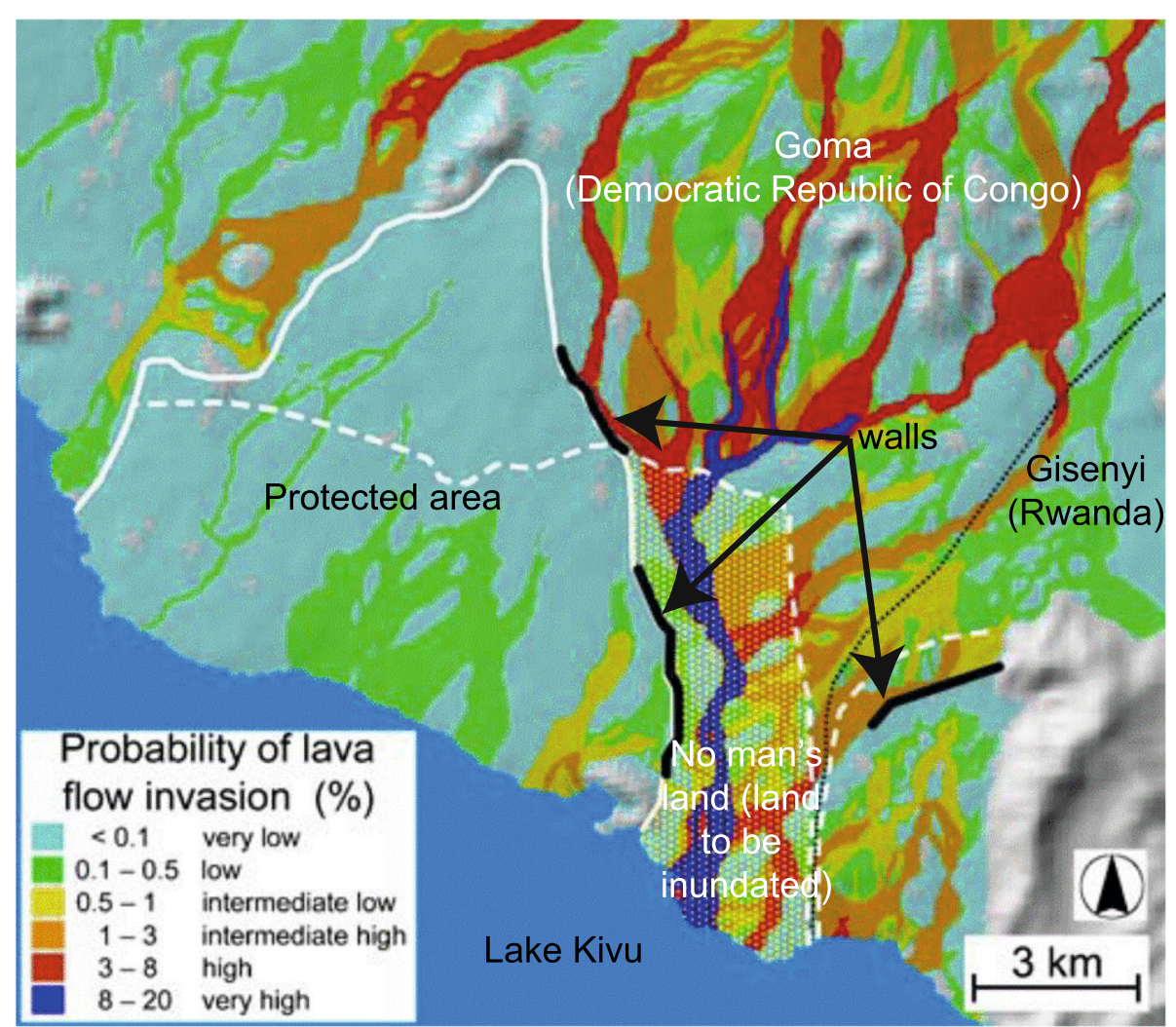

Fig. 4 Map of proposed lava mitigation measures to protect Goma and Gisenyi based on DOWNFLOW lava flow modelling. Structures in the dotted area would need to be relocated. Legend refers to probability of inundation after the walls are built. Modified from Chirico et al. (2009) 
Table 6 Table summarising basaltic lava flow events at Piton de la Fournaise Volcano that have threatened inhabited areas since 1950

\begin{tabular}{|c|c|}
\hline Eruption (References) & Overview, including impacts (Eruptior \\
\hline $1977(1,2,3,6)$ & $\begin{array}{l}\text { Lava flows threatened the town of } \\
\text { Boisblanc and inundated thirty } \\
\text { structures in Piton Ste Rose. A } \\
\text { main road and bridge were also } \\
\text { inundated. ( } 3.5 \text { weeks) }\end{array}$ \\
\hline $1986(1,6)$ & $\begin{array}{l}\text { This eruption consisted of six phases. } \\
\text { During the first phase, the coastal } \\
\text { highway was traversed by two lava } \\
\text { flows. Eight rural houses were } \\
\text { destroyed. During the second phase, } \\
\text { a new fissure opened across the } \\
\text { coastal highway. During the final } \\
\text { phase, a lava tube formed across the } \\
\text { coastal highway. (3.5 years) }\end{array}$ \\
\hline
\end{tabular}

$1998(1,3,6) \quad$ A lava flow threatened Boisblanc although did not reach the town. The old coastal highway was inundated again; the flow stopped $5 \mathrm{~m}$ from inundating the new coastal highway. Forest fires were ignited. (6.25 months)

$2001(1,3,6) \quad$ Two 'a'a lava flows inundated the old coastal highway. (3.5 weeks)

2002 (Jan) $(1,3,6) \quad$ An 'a'â lava flow cut the coastal highway before creating an ocean entry. A lava delta of 15 ha formed. (1.5 weeks)

2002 (Nov) $(1,3,6) \quad$ An 'a'ā lava flow created an ocean entry after traversing the coastal highway. (2 weeks)

2004 (May) $(1,3,6) \quad$ A lava flow threatened to inundate the old coastal highway although stopped $2.5 \mathrm{~km}$ away. Forest fires were ignited. (5.5 months)

2004 (Aug) $(1,3,7) \quad$ A lava delta was created after a lava flow traversed the coastal highway. (3.5 days)

$2005(1,3,6)$

A lava flow advancing at $2.5 \mathrm{~km} / \mathrm{hr}$ inundated the coastal road. A second flow threatened to inundate the road in a second location although stopped $100 \mathrm{~m}$ from the road. (1.5 weeks)

$2007(1,2,3,4,5,7) \quad$ A lava flow effused from a vent on the eastern flank and traversed the coastal highway before reaching the ocean $6 \mathrm{~h}$ later. The resulting laze damaged metal roofs within $1 \mathrm{~km}$ of the ocean entry. By the end of the eruption, $1.4 \mathrm{~km}$ of the coastal highway were inundated while $0.45 \mathrm{~km}^{2}$ of new land was created. This was one of the most voluminous eruptions in centuries, covering forests and igniting fires. (1 month)
Towns were evacuated. Fifty-one people were made homeless by the destruction of their homes.

No response actions reported.

No response actions reported.

No response actions reported.

No response actions reported.

The smoke resulting from the forest fires was used to track the flow's advancement.

No response actions reported.

No response actions reported.

Access to the caldera was limited once the police closed the easy route. A section of the coastal highway was also closed. The town of Le Tremblet was evacuated as a precaution for approximately four days as firefighters fought fires close to the town's access road. The ocean entry impacted sea life with dead fish floating up from depths of up to $500 \mathrm{~m}$ due to the heat of the flow.

No response actions reported.
A new coastal highway was built down slope of the original coastal highway.

Recovery and how these eruptions affected future preparation have not been reported.
The lava tubes are now a tourist attraction.

Recovery and how this eruption affected future preparation has not been reported.

Water and electricity had to be restored to Le Tremblet after residents returned. The Red Cross came to help clean tephra from homes. Tourists were invited to see the ocean entries at the end of the eruption, resulting in the death of one unprepared tourist. The death of fish affected the livelihood of fisherman for an extended period. Sea birds were found dead on the cooling flow. The coastal highway was replaced within a few months (cost: 1 million euro). Newspaper articles noted negative mental health effects. Communication networks took months to be restored. The lava tubes are now a tourist attraction.

Recovery and how this eruption affected future preparation has not been reported. 
Table 7 Table summarising basaltic lava flow events at Karthala that have threatened inhabited areas since 1950

\begin{tabular}{|c|c|c|c|}
\hline Eruption & Overview, including impacts (Eruption duration) & Response & $\begin{array}{l}\text { Recovery \& Preparation for subsequent } \\
\text { eruptions }\end{array}$ \\
\hline 1977 & $\begin{array}{l}\text { A 200-m long fissure opened on the } \\
\text { southwestern flank at } 360 \mathrm{~m} \text { asl. The resulting } \\
\text { 'a'ā lava flow bifurcated with each branch } \\
\text { partially destroying Singani and M'Djoyesi. } \\
\text { The two branches merged at lower elevations } \\
\text { before advancing to the sea. (1 day) }\end{array}$ & $\begin{array}{l}\text { This eruption prompted the evacuation } \\
\text { of more than } 4000 \text { people, primarily in } \\
\text { the damaged villages. Villagers } 1 \mathrm{~km} \text { from } \\
\text { the eruptive vent did not evacuate initially. }\end{array}$ & $\begin{array}{l}\text { Villagers returned several weeks after } \\
\text { the eruption to find their mosques } \\
\text { had not been damaged. The villages } \\
\text { were subsequently rebuilt. This eruption } \\
\text { is celebrated annually on } 5 \text { April. }\end{array}$ \\
\hline
\end{tabular}

Bachelery et al. (2016), Morin and Lavigne (2009), Mossoux et al. (2019), Krafft (1982)

\section{Miyakejima, Miyake Island, Japan}

Miyake Island is also part of the Izu island group off the coast of Japan and south of Toyko. In total, the island is home to approximately four thousand people (Fujita et al. 2003; Furuya et al. 2003) spread across four towns. The towns of Ako, Igaya, Kamitsuki, and Tsubota are all located on the coast. Ako, Kamitsuki, and Tsubota have all be inundated by lava flows in historical times (Cappello et al. 2015). Miyakejima rises in approximately the centre of the island and has two concentric craters although it has frequently produced flank eruptions along regional and local stress fields (Shimozuru et al. 1972) in historical times (Tsukui et al. 2005). Since 1950, Miyakejima has erupted 12 times with the majority of these eruptions occurring in the caldera; only two eruptions have affected the

Table 8 Table summarising basaltic lava flow events at Fogo Volcano that have threatened inhabited areas since 1950

\begin{tabular}{ll}
\hline Eruption (References) & $\begin{array}{l}\text { Overview, including impacts } \\
\text { (Eruption duration) }\end{array}$ \\
\hline $1951(11)$ & $\begin{array}{l}\text { Lava flows inundated agricultural land } \\
\text { and some houses. (2 months) }\end{array}$ \\
& \\
& A fountain-fed lava flow traversed the \\
& primary route to the village of Portela. \\
& After a week, the flow had reached the \\
& outskirts of a village near the crater wall. \\
& Agricultural land, a water reservoir, and \\
& five to ten houses were inundated. The \\
& newly built access route was also \\
& inundated near the end of the flow's \\
& advancement; the lava flow widened \\
& after the flow front halted. The flow \\
& front subsequently reactivated and \\
& consumed a single house in Portela. \\
& After, the lava flow breached its levees \\
& and threatened the access route. It \\
& stopped advancing 2 m away. In total, \\
an entire village, three houses in \\
Portela, and 5 km² of agricultural \\
land were destroyed. (1.5 months)
\end{tabular}

$2014(2,3,4,5,6,7$, This eruption resulted in the inundation $8,9,10,13)$
Response

No response actions reported.

No response actions reported.

In the first day, approximately 1300 people from seven villages were evacuated by foot. Villagers continued to evacuate belongings after an access route was built through agricultural land two weeks after the eruption began. International geologists were asked to aid the local government.
Recovery \& Applying lessons learned

Recovery and how this eruption affected future preparation have not been reported.

Residents of Portela returned regularly to tend their farms and homes and returned permanently after the eruption ended. A partially inundated vineyard was one of the primary businesses in the area, affecting the village's economics for an extended time. A permanent monitoring network was installed after this eruption.
Prior to inundation, both villages and the national park were evacuated. Settlements outside of the caldera also planned to evacuate. During this eruption, responding scientists were remotely supported by modellers using MAGFLOW to determine the potential evolution and impact of the flows.
As of March 2015, buildings and roads were still being excavated and rebuilt. There were lasting economic impacts because of the inundated agricultural land. This eruption can provide significant data for future research as the inundation of both towns was well documented. running north-south in the caldera. Utility and roading networks were also destroyed, leading to access and communication difficulties. In total, more than 230 buildings, $1.2 \mathrm{~km}^{2}$ of agricultural land, and all infrastructure networks in the caldera were damaged or destroyed in this eruption. (2.5 months) churches), a rural settlement, parts of the national park, and the main road

1: Smithsonian Institution's Global Volcanism Network (1995), 2: Adamczyk (2014 December 8), 3: Economist Intelligence Unit (2014), 4: Ministry of Foreign Affairs of Japan (2014 December 19), 5: Al Bawaba (2015 February 4), 6: Fernandes et al. (2015), 7: Worsley (2015), 8: Cappello et al. (2\016), 9: Richter et al. (2016), 10: Jenkins et al. (2017), 11: global volcanism program (2019b), 12: WOVO (n.d.), 13: Komorowski et al. (2018) 
Table 9 Table summarising basaltic lava flow events at Izu-Oshima Volcano that have threatened inhabited areas since 1950

\begin{tabular}{|c|c|c|c|}
\hline Eruption & Overview, including impacts (Eruption duration) & Response & $\begin{array}{l}\text { Recovery \& Applying } \\
\text { lessons learned }\end{array}$ \\
\hline 1986 & $\begin{array}{l}\text { Three 'a'â lava flows were formed. On the first day of } \\
\text { the eruption, a clastogenic, 'a'ā basaltic-andesite lava } \\
\text { flow advanced } 1.5 \mathrm{~km} \text {, to within } 1 \mathrm{~km} \text { of Motomachi. } \\
\text { The town's airport was threatened although never in- } \\
\text { undated. The flow stopped advancing } 200 \mathrm{~m} \text { from } \\
\text { town. The second lava flow in this eruption did not } \\
\text { threaten any structures or necessitate evacuations. The } \\
\text { third and final lava flow, an andesitic, clastogenic lava } \\
\text { flow, approached the local volcanic observatory main- } \\
\text { tained by the University of Tokyo. It stopped flowing } \\
\text { less than half a kilometre before reaching the observa- } \\
\text { tory. ( } 1 \text { month) }\end{array}$ & $\begin{array}{l}\text { In less than half a day, } 12,000 \text { people were evacuated } \\
\text { on } 39 \text { vessels. In order to model the potential threat } \\
\text { to the town, a new lava flow model was developed. } \\
\text { Although lava flow attribute data (such as } \\
\text { temperature and viscosity) are necessary to run the } \\
\text { model presented in Ishihara et al. (1989), the data } \\
\text { used was not measured. Rather, the values were set } \\
\text { based on assumptions relative to previous flows (i.e. } \\
\text { the silica content was higher, so the viscosity was } \\
\text { assumed to be higher). }\end{array}$ & $\begin{array}{l}\text { The evacuations lasted } \\
\text { less than one month as } \\
\text { the eruption was short. }\end{array}$ \\
\hline
\end{tabular}

Watts (1986 November 22), Ishihara et al. (1989), Sawada and Aramaki (1989), Global Volcanism Program (2019c)

island's population (Table 10). Miyakejima is monitored by the Geological Society of Japan.

\section{Mt Cameroon, Cameroon}

Mt. Cameroon is one of Africa's largest volcanoes with a total area of about $1100 \mathrm{~km}^{2}$ and the third tallest mountain in Africa (Njome et al. 2008). As part of the Cameroon Line (a chain of volcanoes extending from northeast Nigeria through Cameroon into the Gulf of Guinea that have been active since the Tertiary), there are more than 100 cinder cones in addition to the main edifice. Three main towns and dozens of smaller villages are scattered around its base with a total population of approximately 500,000 people (Njome et al. 2008; Favalli et al. 2012). Seismometers have monitored Mt Cameroon since the 1980s (Fairhead 1985; Ambeh et al. 1989; Ateba and Ntepe 1997). Lava flows from Mt Cameroon have threatened or indirectly impacted towns five times in the past 70 years (Table 11) with all but one of the vents located on the southern half of the volcano.

\section{La Palma, Canary Islands, Spain}

During the 1971 eruption of La Palma, a lava flow threatened a road although stopped advancing $4 \mathrm{~m}$ before reaching it (Fuster-Casas 1971). The eruption lasted 3 weeks. There is very little published information about this eruption. There have been efforts to strengthen the monitoring at La Palma in recent years.

\section{Scope of gap analysis}

In addition to extracting lessons about how crises have been managed to minimise their social impact (summarised briefly in the overview tables above and in the discussion below), we are interested in collating past data that might be useful to further studies on physical lava flow impacts. With this in mind, we narrowed the scope of our gap analysis to focus on the following eleven data types, described below in order of the preparedness, response and recovery cycle. Note that ten of these are reflected in the summary overviews and tables above while one type is in Electronic Supplemental Material A. After analysing our case studies, we found that

Table 10 Table summarising basaltic lava flow events at Miyakejima Volcano that have threatened inhabited areas since 1950

\begin{tabular}{|c|c|c|c|}
\hline $\begin{array}{l}\text { Eruption } \\
\text { (References) }\end{array}$ & $\begin{array}{l}\text { Overview, including impacts (Eruption } \\
\text { duration) }\end{array}$ & Response & Recovery \& Applying lessons learned \\
\hline $1962(3,4)$ & $\begin{array}{l}\text { A lava flow in the north-eastern sector of } \\
\text { the island destroyed a handful of houses } \\
\text { and the road that circumnavigates the } \\
\text { island. ( } 3 \text { days) }\end{array}$ & Response not reported. & $\begin{array}{l}\text { Physical damage requiring recovery } \\
\text { efforts not reported. }\end{array}$ \\
\hline $1983(1,2,3,4)$ & $\begin{array}{l}\text { Four lava flows caused forest fires and } \\
\text { destruction in two towns, Ako and Usuki. } \\
\text { Up to } 90 \% \text { of Ako was destroyed by the } \\
\text { fires ignited by a lava flow. A subsequent, } \\
\text { smaller flow threatened the rest of Ako. } \\
\text { One of the smaller lava flows also reached } \\
\text { the village of Usuki and buried it. Lava flows } \\
\text { reached the sea in this eruption and added } \\
\text { new land to the island. ( } 1 \text { day) }\end{array}$ & $\begin{array}{l}\text { Most of the housing stock in Ako were } \\
\text { wooden, so firefighters tried to save } \\
\text { structures by spraying them with seawater. } \\
\text { They also tried to cool the lava flow in a } \\
\text { fashion similar to the } 1973 \text { Eldfell eruption } \\
\text { with spraying efforts. Reports suggest that } \\
\text { the cooling effort commenced at the same } \\
\text { time the flow stopped advancing although } \\
\text { efforts continued after the flow stopped } \\
\text { advancing. The switching station in Ako } \\
\text { was destroyed, causing communication } \\
\text { networks to fail. About a third of the island } \\
\text { was successfully evacuated using } 11 \text { buses, } \\
\text { resulting in no fatalities. }\end{array}$ & $\begin{array}{l}\text { Other impacts included electricity } \\
\text { outages of up to one day with one } \\
\text { exception and failure of half of the } \\
\text { water network. Overall, recovery in } \\
\text { areas that were not inundated were } \\
\text { achieved quickly. Ako was abandoned. }\end{array}$ \\
\hline
\end{tabular}


Table 11 Table summarising basaltic lava flow events at Mt. Cameroon that have threatened inhabited areas since 1950

\begin{tabular}{|c|c|c|c|}
\hline $\begin{array}{l}\text { Eruption } \\
\text { (References) }\end{array}$ & $\begin{array}{l}\text { Overview, including impacts } \\
\text { (Eruption duration) }\end{array}$ & Response & Recovery \& Applying lessons learned \\
\hline $1959(1,3,6,7,11)$ & $\begin{array}{l}\text { Villages and fields were threatened } \\
\text { by 'a'ā lava flows. ( } 1.5 \text { months) }\end{array}$ & Response not reported. & $\begin{array}{l}\text { Recovery and how this eruption affected } \\
\text { future preparation were not reported. }\end{array}$ \\
\hline $1982(2,3,11)$ & $\begin{array}{l}\text { 'A'à lava flows advanced at } 20 \mathrm{~km} / \mathrm{hr} \\
\text { through dense forests towards the } \\
\text { town of Bakingili ( } 6 \mathrm{~km} \text { from the vent). } \\
\text { (1 month) }\end{array}$ & $\begin{array}{l}\text { As a result, three towns were evacuated. } \\
\text { Although none of the towns were } \\
\text { inundated, many palm oil plantations } \\
\text { were; other local economies were } \\
\text { unaffected. }\end{array}$ & $\begin{array}{l}\text { Recovery and how this eruption affected } \\
\text { future preparation were not reported. }\end{array}$ \\
\hline $\begin{array}{l}1999(4,5,6,9,10 \\
11)\end{array}$ & $\begin{array}{l}\text { Bakingili was threatened again by an } \\
\text { 'a'ā lava flow that advanced through } \\
\text { forests. Hundreds of acres of forests } \\
\text { and palm oil trees were destroyed by } \\
\text { inundation and ignition. The lava flow } \\
\text { inundated a hundred metre stretch } \\
\text { of road before reaching the ocean. } \\
\text { ( } 3 \text { weeks) }\end{array}$ & $\begin{array}{l}\text { Due to the resulting laze, two towns } \\
\text { were evacuated. Within six days of the } \\
\text { flow emplacement, people were already } \\
\text { observed climbing over the flow. }\end{array}$ & $\begin{array}{l}\text { Within two months of the end of the } \\
\text { eruption, all evacuees had returned home. }\end{array}$ \\
\hline $2000(5,8,10,11)$ & $\begin{array}{l}\text { 'A'ā lava flows advanced through } \\
\text { savannahs, forests, and agricultural } \\
\text { land before threatening suburbs in } \\
\text { Buea. The flows advanced at } 30 \mathrm{~m} / \mathrm{hr} \\
\text { although stopped advancing } 4 \mathrm{~km} \\
\text { from the outskirts of town. While the } \\
\text { town itself was spared, the lava flow } \\
\text { traversed the road near Limbe. } \\
\text { ( } 3.5 \text { months) }\end{array}$ & $\begin{array}{l}\text { Local officials began evacuation planning } \\
\text { for } 3000 \text { people although the plans were } \\
\text { never implemented as the flow stopped } \\
\text { advancing after two days, } 4 \mathrm{~km} \text { from Buea. }\end{array}$ & $\begin{array}{l}\text { Recovery and how this eruption affected } \\
\text { future preparation were not reported. }\end{array}$ \\
\hline
\end{tabular}

1: Jennings (1959), 2: Fitton et al. (1983), 3: Deruelle et al. (1987), 4: Deruelle et al. (2000), 5: Suh et al. (2003), 6: Bonne et al. (2008), 7: Njome et al. (2008), 8: Ateba et al. (2009), 9: Suh et al. (2011), 10: Favalli et al. (2012), 11: Global Volcanism Program (2019a)

many of our data types have not been consistently documented in a detailed fashion; thus, many of our data types of interest have not been consistently included in the volcano overviews, in the above tables, or in Electronic Supplemental Material A.

\section{Preparation actions and narrative}

We analysed published literature for preparation actions and narratives (e.g. Brantley et al. 2019), i.e. documentation of precursory activity and preparation actions undertaken prior to the eruption onset. The creation of hazard maps is one example preparation action. Installing and maintaining monitoring networks is another example of a preparation method that may be undertaken; such data is typically collected by the local volcano observatory or equivalent scientific body. All published monitoring data, including data in journal articles or on institutional websites, counted as evidence of preparatory actions which could contribute to preparatory narratives and thus counted towards a " $x$ " (data available) in Table 12. Another example of a preparation action could be zoning of land to decrease the number of people living in an area deemed to be high risk for lava flow inundation. Commonly, scientific preparation actions and narratives are mentioned in the beginning of an eruptive narrative paper, and frequently include description of the relationship between the scientists and the local government authorities who also undertake preparation measures upon notice of an impending eruption. This data type is not included in the summary tables (Tables $1,2,3,4,5,6,7,8,9,10$ and 11$)$.

\section{Lava flow hazard modelling}

Lava flow hazard modelling can be undertaken prior to an eruption to help identify areas that are at high risk of inundation (e.g. Bonne et al. 2008; Chirico et al. 2009; Favalli et al. 2009a, 2009b; Harris et al. 2011; Cappello et al. 2015; Tarquini et al. 2019) or during an eruption to plan evacuations (e.g. Ishihara et al. 1989; Dobran and Macedonio 1992). The case studies were analysed for descriptions of both types of lava flow modelling. Any published instance of lava flow modelling being used during an eruption counted towards as data collected (i.e. an " $x$ ") in Table 12. This data type is referenced in the response column of the summary tables.

\section{Eruption narrative}

An eruptive narrative is an overview description of the eruption, including all of the volcanic processes that occurred. It provides context for any detailed data collected and could support why response actions were taken at specific times. Two examples are the narrative of the 1971 eruption of Etna by Huntington (1972) and the "Chronology of the eruption" section of the Barberi et al. (1993) account of the 1991-1993 Etna eruption. While these examples provide extensive detail about the eruptions in question, we counted any account of the eruption that provided a narrative timeline of the 


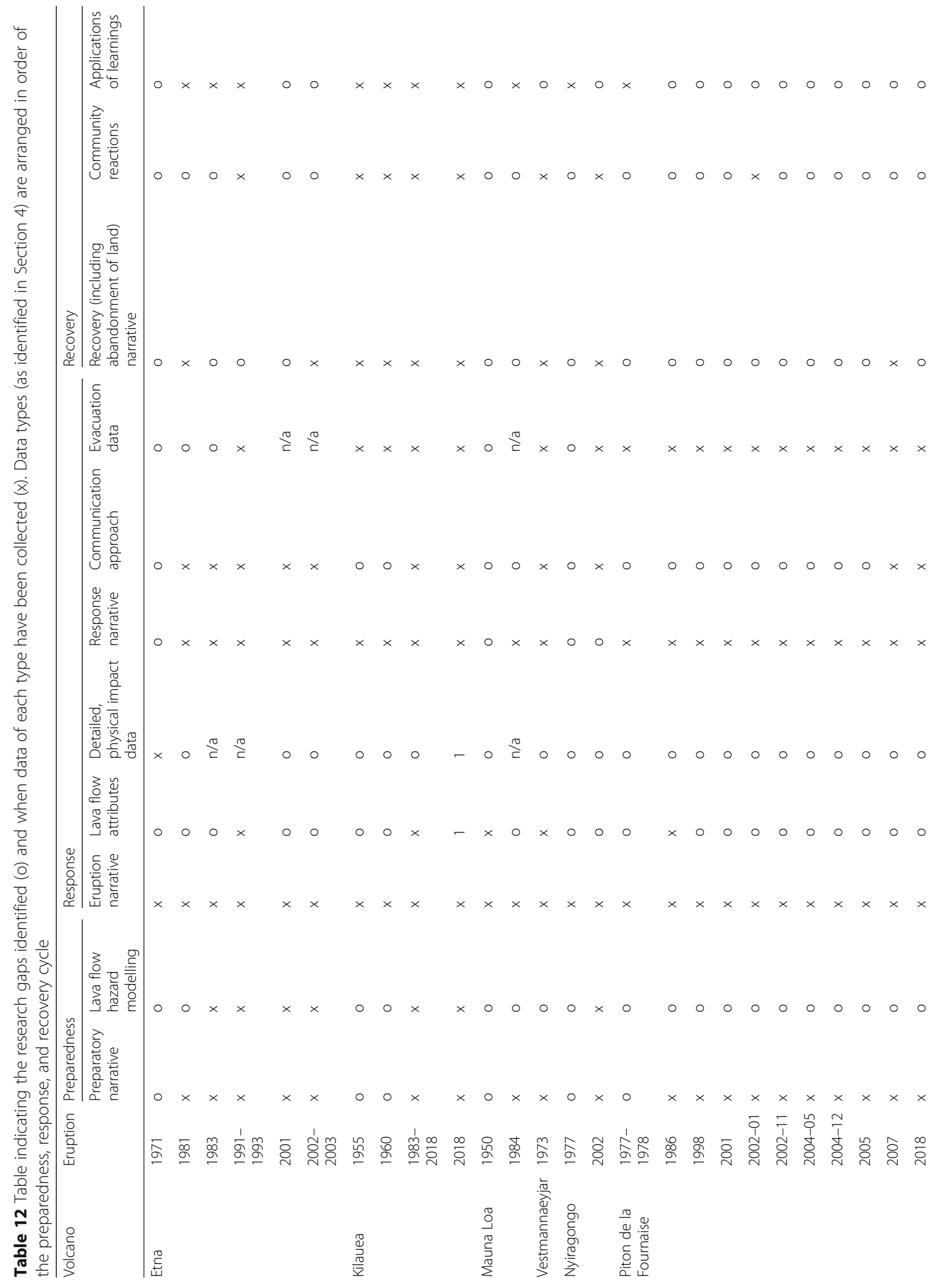




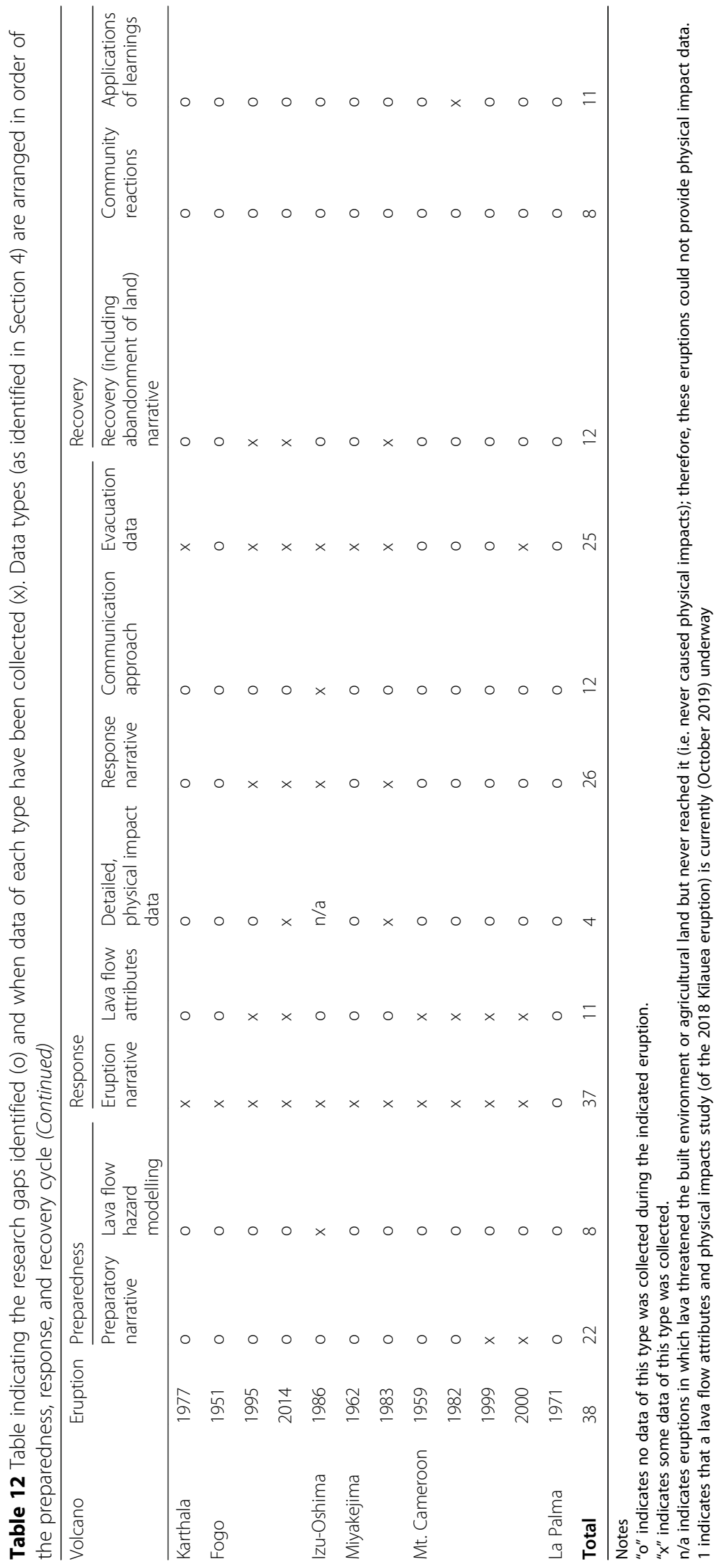


eruption towards data collected (i.e. an "x") in Table 12. This data type is included in the overview column of the summary tables.

\section{Lava flow attributes}

There are many attributes used to describe lava flows. For example, a lava flow's flow front advancement rate, temperature, or geochemistry can be described. These attributes influence the flow's morphology and the hazard it poses. They also may be used as criteria to determine if one lava flow is analogous to another. Some of these attributes must be recorded during the eruption as they change with time (e.g. lava flow core temperature at a given location) while others can be measured after an eruption ends (e.g. bulk geochemistry, final flow dimensions). As this data type is very broad, it can be difficult for any single study to be comprehensive. Often, certain attributes are published in more details than others. Thus, we have assigned data collected symbols (i.e. "x" symbols) to eruptions that have at least several attributes described over time. We emphasise that does not mean every attribute has been collected, but that this eruption is better studied than eruptions with a no data collected symbol (i.e. an "o"). Given that we have already narrowed our case studies to basaltic eruptions (Section 1.1), we did not analyse the case studies for geochemical data. This data is included in Electronic Supplemental Material A in instances where it is publicly available.

\section{Detailed physical impact data}

In order to enable the creation of lava flow vulnerability models, detailed physical impact data is needed (Wilson et al. 2017). Impact data consist of a description of the damage observed. This data could be collected by field teams or by more remote methods such as unmanned aerial systems or satellite imagery. For example, the impact data collected by a field team could be "all concrete within $1 \mathrm{~m}$ of the lava flow front spaulded." The location, time, and date of the data should be noted, and ideally, images should be taken. Since the localised hazard caused the damage being documented, localised lava flow attributes are necessary. To continue with the example above, lava flow attribute data such as the local temperature of the flow front are needed. The height of the flow front and how cohesive the flow front is could also be important. Impacts are dependent on the vulnerability of the asset, which should also be recorded. In the field, this often translates to details about what the structure is made of, angles of the structure, an estimate of how old the structure may be, etc. Alternatively, camera footage collected using unmanned aerial systems can be analysed for damage to structures near the edge of the flow. At this scale, damage could include singe marks or budging of fences or walls. Similarly, satellite imagery can also be used to classify building types by material. Repeat flybys would enable progressive damage states to be documented. It is also important to note that some of this data can also be estimated and/or extracted from overlaying final lava footprints over infrastructural maps and/or remote sensing imagery.

Recent eruptions challenge the notion that lava flows always cause binary impacts (i.e. either complete destruction or no damage at all, depending on whether the lava is in contact with the structure of interest), but the creation of vulnerability models depends on sufficient data about the potential range of impacts (Jenkins et al. 2014; Wilson et al. 2014). Data from multiple eruptions is required to ensure vulnerability models are widely applicable (Wilson 2015). As this data type can aid in future studies that aim to build vulnerability models, the bar for a data collected symbol in Table 12 was high. Not only did an impact have to be recorded, but at least a few details about the impacted structure needed to be included (i.e. the damaged buildings were wooden). This data is included in the response column of the summary tables.

\section{Response narrative}

A response narrative is a description of the response actions taken because of the eruption. Anyone affected by the eruption could have undertaken response actions. For example, a scientist may hold a press conference to inform the public about the eruption, a government official may call an evacuation, or a community member may buy a generator in case they lose electricity. Ideally, all of these actions are documented with an explanation about what triggered each action (e.g. lava flow modelling indicated Zafferana Etnea could be inundated by lava if the eruption lasted long enough, prompting the creation of lava flow diversion measures; Table 1). The criteria for an eruption to be awarded a data collected symbol for a recovery narrative in Table 12 was very similar to the criteria used for eruption narrative. We searched for a narrative timeline of actions undertaken; we posit that the narratives that include rationales could be more useful to future studies than those without such rationales. For example, a narrative that includes data such as "we issued an evacuation order because the flow front was $1 \mathrm{~km}$ away" not only provides the response action undertaken but also why it was undertaken. Thus, this criteria could be included in future plans or be adapted if improvement was needed. This data type is included in the response column of the summary tables.

\section{Communication approaches}

Once an eruption commences, the official communication between scientists, government officials, and the public can influence the effectiveness of public and 
private response actions (e.g. Brantley et al. 2019; Ching et al., 2020) or cause mistrust of public officials. We analysed the case studies for a published communication strategy (e.g. Brantley et al. 2019) and for evidence that official communication was occurring. In the latter case, quotes from scientists or emergency managers in newspaper articles were considered evidence that scientists and/or emergency managers sought to communicate with the public. Either a published account of a communication approach (e.g. Brantley et al. 2019) or newspaper articles quoting scientists or emergency managers counted towards an eruption being awarded a " $\mathrm{x}$ " in Table 12. This data type is not included in the summary tables.

\section{Evacuation data}

Evacuations are one common type of governmental response action to a lava flow crisis (e.g. Watts 1986). An evacuation can have both social and economic impacts. How evacuations are implemented can affect how well exclusion zones are maintained (e.g. Williams and Moore 1983; Lacey 2002a, 2002b). For example, first responders have commented that the non-binding evacuation order issued during Kîlauea's Lower East Rift Zone Eruption in 2018 made it implement exclusion zones (Tsang and Lindsay 2019). We looked for comments on evacuations in journal articles as well as Global Volcanism Bulletin reports and newspaper articles. Some of the evacuations in response to eruptions were voluntary while others were mandatory and enforced by government officials. In order to be awarded an " $x$ " in Table 12 , there had to be published information that an evacuation occurred and there had to be at least some information about its nature (e.g. did people leave on their own accord). Some evacuations were described in detail (e.g. how quickly they occurred, by what transportation means, when people returned). We suggest that these more detailed evacuation data are more useful when extracting lessons and are, therefore, preferable. This data type is included in the response column in the summary tables.

\section{Recovery narrative}

After an eruption, communities and affected land often undergo a recovery period. We analysed the literature for recovery narratives. These descriptions of how the land and communities recover over time after an eruption can indicate how severe an eruption was as well as providing details about necessary clean-up actions, potential positive outcomes from an eruption (e.g. Williams and Moore 1983), and how long it could be until land can be used again. All of these descriptions of recovery can help for future eruptions. When searching for such narratives, it is important to note that recovery narratives can exist even if physical impacts have not been documented, as recovery also includes nonphysical recovery, sometimes described at a community level without reference to detailed physical impact data. Similar to eruptive and response narratives, a narrative timeline of recovery actions needed to be publicly available in order to be awarded an " $x$ " in Table 12. This data type is included in the recovery column of the summary tables.

\section{Community reactions}

Community reactions to actions taken during the emergency management cycle are needed to evaluate whether actions functioned well/as intended or needed improvement (Ching et al., 2020). Examples of positive community reactions would be a local business member saying that an emergency manager's daily visits helped in decision-making or residents reporting feeling comforted by earthen barriers (where the positivity of a reaction is based on the community members' feelings). We were looking for either peer-reviewed and/or grey literature that was written by (or relied on interview data from) community members to receive an " $x$ " for this category in Table 12. This data type is not included in the summary tables.

\section{Applying lessons learned}

After an eruption is over, applying the lessons learned from an eruption is a way to ensure mistakes are not repeated and responses are improved (e.g. Nairn and Scott 1995; Durand et al. 2001; Sword-Daniels et al. 2011; Blake et al. 2015). We looked in the literature for documented actions taken after an eruption that could help in a future eruption sequence. For example, after the 1977 Piton de la Fournaise eruption, a monitoring network was installed (e.g. Lenat 2016; Staudacher et al. 2016). This data type can be difficult to elicit as the application of lessons learned could be in confidential files; in order to ascribe an eruption an " $x$ " in Table 12, we looked for documentation that changes had been made in response to the eruption. This documentation was sometimes found near the end of impact reports, or in the form of recent research describing changes since a previous eruption. This is included in the applying lessons learned column in the summary tables.

\section{Gap analysis}

Most of the literature on lava flow crises comes from media reports (i.e. non-peer reviewed sources) or the Smithsonian Institute's Bulletin of Volcanic Eruptions. The Bulletin Reports are based on field reports from responding scientists. As the reports do not have a standard format, the information in each report varies significantly. 
We found that many of our identified data types have been reported in our literature review (Table 12). More than half of the eruptions (at least 19) that we examined contained eruption and response narratives, and evacuation data. Although the amount of data and number of details recorded varies significantly from one eruption to the next and one volcano to another, these data types seem to be reported on with increasing frequency during the period of time covered by the study. Communication approaches and preparation and recovery narratives have been published for at least one quarter of the eruptions (more than 11 eruptions). As these data types are also increasing in frequency in the form of published work (e.g. Fearnly et al. 2018) and government documents (e.g. CDEM 2015; County of Hawai'i 2019), we do not discuss them further here.

Five data types (lava flow hazard modelling, lava flow attributes, physical impacts, community reactions, and applications of learnings) have been published in less than a quarter of eruptions (i.e. 11 eruptions or less) and are the focus of the remainder of this section, with a suggestion that in future scientists should consider collecting such data when possible.

\section{Lava flow attributes}

This data type covers many types of primarily quantitative data. Some categories of lava flow attribute data, such as a flow's petrology, are already well documented. The reporting of other categories, such as the effusion rate, surficial temperature, and inflation rates, are already improving with new technologies such as remote sensing hotspot detection (Harris et al. 2016a) and unmanned aerial systems (e.g. Turner et al. 2017). Still other categories, such as internal temperatures, are not as frequently published (Electronic Supplemental Material A). When these least frequently reported categories of data are reported, it is often in Global Volcanism Program Bulletin Reports, but their inclusion is not consistent. Increasing how often these data are published compared to the rates that other data (such as a flow's petrology) are published would enable many different types of studies, such as lava flow process studies, the creation of vulnerability models (Wilson 2015), and additional modelling benchmark case studies (Cordonnier et al. 2016; Dietterich et al. 2017).

\section{Lava flow hazard modelling}

Aspects of lava flow hazard modelling have been well documented. For example, Harris et al. (2016a) provided an overview of current lava flow areal footprint models in 2016, provide suggested best practices (Harris et al. 2016b), describe an example of how lava flow modelling can be integrated with GIS (Latutrie et al. 2016), and introduced benchmarking exercises for them (e.g.
Cordonnier et al. 2016). Since, additional work on using GIS to support lava flow modelling and impact assessments has been conducted (e.g. Davoine and Saint-Marc 2016; Mossoux et al. 2019), and there has been extensive work about how lava flow models can be used after recovery (e.g. Tarquini and Favalli 2016; Scifoni et al. 2010). Despite extensive documentation on lava flow hazard models themselves and hazard modelling during some of the case study eruptions, reports do not consistently indicate attempted unsuccessful modelling, why modelling was not undertaken, if modelling had been undertaken prior to the eruption onset, whether and how modelling results informed hazard communication products such as hazard maps, and how modelling results have influenced actions before or during an eruption. Insights, including when modelling has not been undertaken or did not produce results in an expected manner, can provide useful information for modifying models and preparing for future eruptions. Additionally, context around lava flow hazard modelling could help emergency managers who have not responded to an effusive crisis before in their planning.

\section{Impact data}

Details about lava flow impacts are especially sparse. Impact data is frequently limited to broad statements such as "two lava flows issued from the fissure, cutting the main circum-island road" (Global Volcanism Program $2019 \mathrm{~g}$ ) or "lava buried $80 \%$ of the coast[al] town" (Global Volcanism Program 2019e). More useful reports would include more detailed information. For example, the coastal town could be described with additional details such as what the buildings were made of or if the burning was limited to within a few metres of the lava flow. Similarly, after the eruption ends, it would be useful to document how far away from the fissure the damage extended. Potential information could include how far away from the fissure volcanic ejecta have been deposited (which could potentially help volcanic ballistics research) but also if there is any evidence of heat damage at distance from the lava flow(s) (which could provide information for thermal modelling of lava). An example of this is included on page 32 of Tsang (2019b) when discussing the remediation of the Pāhoa Transfer Station after the June $27^{\text {th }}$ Lava Flow.

\section{Community reactions}

Evacuations are relatively commonly documented in literature, but the details (such as how the evacuated residents coped with being evacuated, when exclusion zones were lifted, and what event triggered the lifting of an evacuation or exclusion zone) are generally lacking. Such data can aid in planning pre-eruption messaging and when drafting plans. Published reports suggest that some 
evacuation zones have more support from residents and maintain their function more efficiently. Comparing events in which residents returned to an evacuation zone during an eruption (e.g. during the Fogo 2014-2015 eruption) to those in which residents did not return to an evacuation zone during an eruption (e.g. during most Piton de la Fournaise eruptions) could help extract evacuation zone best practices. Community member opinions on how messaging about evacuations helped or hindered their evacuation process enables best practices to emerge (e.g. community members commenting that lava flow front arrival times would have helped them time their evacuations more appropriately in Kilauea's June $27^{\text {th }}$ Lava Flow in 2014-2015 (Ching et al., 2020)).

\section{Applying lessons learned}

While some businesses prepare extensively for natural hazards, documentation is frequently internal and confidential. It is rare for preparation actions and trainings by the local community and industry to be documented, but knowledge of such actions could aid the planning in other areas where the local volcano has been dormant or since the area became populated.

Additionally, reports of an eruption tend to cover the eruption onset through the end of the activity without reflecting on long-term impacts of the eruption. Analysis of how processes functioned would preserve institutional history for people or groups that experienced the eruption and would teach other people who may experience similar situations in the future (e.g. Nairn and Scott 1995; Durand et al. 2001; Sword-Daniels et al. 2011; Blake et al. 2015). In some cases, this analysis may be done internally (e.g. Black 2019), but internal documents that are not shared do not benefit the wider community (e.g. Black 2019).

\section{Discussion}

Although lava flows directly impact fewer urban centres per eruption compared to other more distributed volcanic hazards such as tephra, the numerous lava flow crises since 1950 reveal that lava flows can have significant impacts on communities. Since lava flow crises can have expensive and/or lasting effects on communities, it is important to consider if lava flow impacts can be mitigated. In order to make such a determination, several more basic questions - such as how do lava flows cause damage, how frequently do lava flows exhibit the qualities that cause damage, what mitigation measures have communities tested, and were they successful - need to be answered first. This work represents the first step towards answering those basic questions by collating peer-reviewed and grey literature on lava flow crises.

\section{Documentation of eruptions}

When analysing lava flow crises since 1950, it is evident that more recent eruptions and eruptions in which large, novel mitigation measures were implemented have been more thoroughly documented than other, older eruptions. For example, less than a year after the last active surficial lava was seen in the 2018 Kilauea Lower East Rift Zone eruption, a journal article, at least 73 scientific abstracts, and more than 6100 newspaper articles had already all been published online. Such online access to information does not exist for older eruptions, likely due to a range of factors: older literature may not have been published online nor digitised; grey literature may not remain online indefinitely; and because international access to eruptions has not always been as easy, leading to fewer scientific studies. Additionally, it has become easier to self-publish articles online via blogs and personal websites. More eruption details are routinely being catalogued today than in the past. With more data preservation, it is possible to begin collecting systematic data across eruptions and volcanoes. Here we suggest 11 different themes for which data should be collected to improve our understanding of lava flow impacts and their social implications. Five of these themes are underreported and create gaps in our understanding of past crises.

Although this collation of lava flow crises shows enormous progress both in how communities respond to lava flows and in what data is collected during effusive eruptions, the data presented could be augmented to aid in lava flow vulnerability models and response and recovery best practices. The eruptions described suggest there is nuance to the impacts lava flows can have, but our current damage paradigm (i.e. binary vulnerability model) does not reflect this. Since data after an eruption are currently collected based on the field geologist's interests and time, impact data is not always collected or made widely accessible. Perhaps it is time to consider creating a database with standardised data, such as an expanded, crowd-sourced version of lava flow data in the Critical Infrastructure Volcanic Impacts Database proposed by Wilson (2015). One way to achieve this would be to standardise the data collection process, similar to what has been done for seismic damage (MBIE 2017). Although an expansion of the Critical Volcanic Impacts Database implies a focus on physical impact data, many of the other referenced data types would also need to be stored to provide context for the impact data. For example, in order to understand a concrete wall spaudling (a physical impact), it would be important to know how close the lava flow was, how hot it was, and how long it was present in the final location. These are all examples of lava flow attributes. Additional data about the concrete itself would also help; for example, 
the age of the concrete would have implications about its water content, which in turn affects spaulding. If the concrete wall was part of a mitigation barrier, why was this material selected and put in place at the given time? Thus, while the impetus of expanding the Critical Infrastructure Volcanic Impacts Database to more than infrastructure would be to improve lava flow hazard and impact studies, most of the data types described in Section 4 should also be included in some form. The data in such a database could also inform best practices after lava flow crises to help guide actions related to future eruptions and to aid people who may experience a lava flow crises but have not yet. In order to establish best practices, more data about the context around the lava flow, the decisions made, the rationale for said decisions, and the outcome of actions need to be documented.

\section{Lessons from previous eruptions}

One motivation to collate data on past lava flow inundations was to examine eruptions critically to collect lessons learned that can inform preparation, response, and recovery plans at analogue volcanoes. Although we identified several key gaps during our literature review of lava flow inundations since 1950, we were also able to extract some key lessons that may be useful for other areas. We group these lessons into five categories: community understanding, land use planning, evacuations, mitigation, and recovery. Lessons from each category are presented below.

\section{Community understanding of the hazard}

Communities that are more informed about volcanic hazards tend to be more resilient to the negative consequences of eruptions. One of the key learnings from Piton de la Fournaise that could be applied elsewhere is understanding the surrounding communities' knowledge of the volcano. Nave et al. (2016) found a positive correlation between community understanding of volcanic hazards and preparation for eruptions on the flanks of Piton de la Fournaise (Table 6). This suggests increasing community understanding of the hazard could aid in other locations although may prove difficult in areas where the local volcano is not as active. In fact, some researchers are actively working to improve community understanding through novel outreach such as the game HAZGORA (Mossoux et al. 2016). One method may be to capitalise on local indigenous knowledge and culture. In Iceland, individuals were found to be more resilient to and knowledgeable about volcanic phenomena due to mythologies (Bird et al. 2011). Research on community resilience after the June $27^{\text {th }}$ Lava Flow at Kilauea showed similar results: mythology and oral traditions have had a demonstrable effect on community and individual resilience and understanding of the hazard (Ching et al., 2020). Future research could include relating communication strategies to a community's understanding of volcanic hazards.

\section{Hazard modelling to inform planning}

Studies and eruptions at several of the volcanoes have demonstrated how lava flow footprint modelling can be used to inform planning before, during, and after eruptions. After the 1986 Izu-Oshima eruption threatened towns and key infrastructure, a lava flow model was created to determine other areas at high risk of inundation (Ishihara et al. 1989). This study underscores how lava flow modelling can be used during and after a crisis to predict which areas are at highest risk and enables informed planning. Scientists have undertaken taken similar work to inform mitigation measure placement during Etna eruptions since the early 1990s (e.g. Dobran and Macedonio 1992; Barberi et al. 2003). Lava flow hazard maps created based on lava flow modelling outputs prior to an eruption can be compared with actual areas inundated by lava flows to evaluate the efficacy of both the maps and the modelling outputs.

Modelling conducted after eruptions can also be useful. For example, the 1977 and 2002 Nyiragongo eruptions emphasised that the foiditic composition of the lava can produce flows that advance very quickly. After the 2002 eruption, probabilistic lava flow modelling was undertaken (Chirico et al. 2009) to inform preparedness and allow for mitigation planning. The results of the modelling demonstrated that the "no man's land" between the Democratic Republic of Congo and Rwanda would be a realistic place to redirect lava flows (Chirico et al. 2009). Due to the speed of the lava flows in the area, measures to divert flows into the empty land must be in place before the lava begins erupting.

While this tactic may work in a location like Goma where large areas of open space can be zoned, this mitigation measure may not work as well in other cities. Such modelling studies are important because they establish that a volcano without numerous background studies detailing the lava flow's attributes can still benefit from hazard modelling to inform planning. Hazard modelling studies can benefit from additional lava flow attribute data, which can inform benchmarking studies such as Cordonnier et al. (2016) and Dietterich et al. (2017).

\section{Evacuations}

Two evacuation lessons can be extracted from the case studies: 1) Lava flow secondary hazards can be severe enough to require evacuations, and 2) boat evacuations can be highly efficient both in terms of timing and in maintaining security. When a lava flow threatens a community, evacuations are frequently called for primary or secondary hazards. The eruptions at Mt Cameroon 
emphasise that lava flows' secondary hazards, such as fires and laze, can pose an important hazard both to the built environment and to people's health (Global Volcanism Program 2019a). Although towns in Cameroon have not been evacuated because of lava flows themselves, they have been evacuated due to poor air quality due to local forests burning (e.g., the 1999 Mt. Cameroon eruption in which Bakingili and Batoke were evacuated (Global Volcanism Program 2019a)). During both the 1973 Vestmannaeyjar Volcanic Field (Iceland) and the 1986 Izu-Oshima eruptions, whole island evacuations were conducted using industrial boats (Watts 1986; McPhee 1989). The evacuations both relocated the vast majority of the islands' populations and were completed in less than a day (Watts 1986; McPhee 1989). On Heimaey the evacuation meant access to the exclusion area was strictly controlled with first responders evacuating buildings as needed (McPhee 1989). By strictly limiting who could enter the exclusion area, identifying who was allowed to be in a cordoned area was easier (than in eruptions elsewhere), and there were no reports of looting. It has also been posited that by limiting how many belongings were evacuated, the repopulation process was likely faster after the evacuation order was lifted (Williams and Moore 1983; McPhee 1989). Evacuation data is generally well reported and can inform planning actions.

\section{Physical mitigation measures}

Although structural mitigation actions can introduce unacceptable legal liabilities, mitigation actions have been shown to be effective in several eruptions. Mitigating damage caused by lava flows generally takes an avoidance approach, i.e. communities see diverting flows as the best way to mitigate damage to an area. When mitigating potential damage from lava flows, the goal is not to protect everything; it is simply to protect the most valuable asset(s). Dropping objects in lava flows to slow their advance has been tested although has always been deemed unsuccessful (e.g. Barberi et al. 1993). Three methods have been tested and shown to be successful.

1. Diversion barriers. As diversion barriers are only useful at stalling a lava flow they represent a method to buy extra time to move people and objects away from the projected lava flow course or to build a different redirection method such as an artificial channel (Barberi et al. 1993). They have been tested during multiple eruptions at Mt. Etna. Although Macdonald (1975) states that 'a'ā lava flows cannot be redirected using earthen barriers due to their high viscosities compared to pāhoehoe flows, Italian efforts to protect the built environment show otherwise (Barberi et al. 1993). During Kïlauea's 1955 and 1960 eruptions, diversion barriers were constructed although overtopped. These barriers demonstrate that even if an earthen barrier is overtopped, it may have protected the community (Barberi et al. 1993). If the eruption ends shortly after the barrier is overtopped, the lava flow might not inundate the asset it is protecting (Stewart 2014).

2. Redirection channels. Because it is potentially problematic that lava flows thicken and overtop diversion barriers, Italians have pioneered redirection channels (Barberi et al. 1993). The first attempt was undertaken in 1983 and did not divert a significant portion of the lava (Tsang and Lindsay, in prep). During the second attempt in the 1991-3 eruption, the hole in the side of the lava tube was significantly larger and diverted more of the flow (Barberi et al. 1993). Scientists credit the success of the second attempt to lessons from the first attempt, e.g. they learned that cooling the wall of the lava tube to insert the explosives made the explosives less effective (Tsang and Lindsay, in prep). They also found that a redirection channel only needs to be angled a few degrees subparallel to the natural channel to be effective (Scifoni et al. 2010). The final redirection channel lesson is that there is rarely a good place into which lava can be redirected (e.g. Chirico et al. 2009). Although towns were threatened during the Mt Etna 1991-1993 eruption (Table 1), any lava flow redirection would have sent lava into land covered by native bush (Carapezza 2017). Thus, the local environmentalist community did not support the lava flow redirection (Schanche 1983; Carapezza 2017).

3. Lava cooling. The third lava mitigation measure has been referred to as "watering the flow" and has been tested during the 1973 Vestmannaeyjar and 1983 Miyakejima eruptions. The Vestmannaeyjar eruption was the first eruption in which water was successfully used to protect an area (Williams and Moore 1983; Aramaki et al. 1986). The success can be attributed to many factors, including an endless supply of water from the adjacent harbour and a fortunate timing to the end of the eruption (McPhee 1989). The Miyakejima eruption demonstrated success with an order of magnitude less total water volume, rate at which the water was sprayed, and amount of water normalised by total volume of lava than the Vestmannaeyjar eruption, but the success of this method can be at least partially attributed to the timing of the end of each eruption.

Although each of these mitigation measures has been enacted after the eruption onset, scientists have begun 
holding mitigation measure discussions during preparation phases of the disaster planning cycle. For example, lava flow modelling studies at Nyiragongo have pinpointed the best place to redirect lava flows and proposed diversion barriers (Chirico et al. 2009). Discussions about Mauna Loa lava flows have progressed even farther. Mitigation measures have been considered so far in advance that lava protection walls are erected at the same time assets with high community value are built, such as around the USA's National Ocean and Atmospheric Administration's Mauna Loa Observatory (Pipkin et al. 2010; Kauahikaua and Tilling 2014). This is one approach to lava flow diversions and mitigations and should be noted as an important lesson for areas that could have rapid-onset eruptions.

The legal liability of such actions needs to be carefully considered. Legally, governments in Hawaii do not want to accept the liability of destroying one asset to protect another (MacDonald 1958; Poland et al. 2015). The exception to this rule was created during discussions during the 1984 lava flows (Poland et al. 2015). When a highly valuable community asset, such as the Hilo Hospital, is threatened by a lava flow, officials in Hawaii are willing to consider mitigating the impact of the lava flow on this asset by diverting the flow (Poland et al. 2015).

\section{Recovery}

Anecdotes from after lava flow crisis suggest two lessons about lava flow damage: 1) lava flow damage may not be binary, and 2) assets can sometimes be reused again after eruptions. Although lava flows are often considered to cause binary damage, it is not unheard of for communities to become re-established after a lava flow crisis is over. Within two years after the 1973 Eldfell eruption, $85 \%$ of the town's population had returned (Williams and Moore 1983). Fish processing plants which had been partially surrounded by lava were functioning again (Williams and Moore 1983). For over a decade after the eruption, heat from the lava flow was being harnessed to heat Heimaey's water and provide electricity to the town (Williams and Moore 1983). In less than a month after lava flows traversed the city of Goma, people had returned home and continued about their daily business (Lacey 2002a, 2002b). Less than a year after the town of Portela was inundated by the 2014 Fogo eruption, the community was rebuilding and unburying buildings (Jenkins et al. 2017).

\section{Conclusion}

Although lava flow crises capture the world's attention, they are not as rigorously documented by the scientific community as other volcanic hazards are, nor have they been systematically compared in order to investigate research gaps, best practices, or vulnerability models. Here, we summarise all basaltic lava flow crises since 1950 that have been described in scientific or grey literature. After analysing the published record, it becomes apparent that certain types of data - such as physical impact data, community reactions to the crisis, how people prepared for the crisis, and how the crisis affected preparations after the eruption - are rarely recorded. Additionally, lava flow attribute data and the context and decisionmaking around lava flow modelling undertaken during a crisis are not consistently published. Thus, we recommend a larger community discussion about how to collect and catalogue the suggested data, which can aid in collating information about lava flow impacts and societal effects, and best practices associated with managing lava flow crises. Here, we presented lessons about how increased community understanding of lava flows enhances community response during an eruption and how lava flow modelling can assist in planning. Our literature review also demonstrated that some evacuation policies are more effective than others, that some lava flow mitigation measures have been successful, and that inundated land can be reused.

\section{Supplementary information}

Supplementary information accompanies this paper at https://doi.org/10. 1186/s13617-020-00096-y.

\section{Additional file 1.}

Additional file 2 .

\section{Acknowledgements}

We would like to thank Kate Kenedi for reviewing the manuscript for clarity and brevity!. We also greatly appreciate the thoughtful reviews of two anonymous reviewers and Simone Tarquini; their comments greatly improved this manuscript. We would like to acknowledge Dr. David Damby for his editorial handling of this paper.

\section{Authors' contributions}

Both authors conceived this study and contributed to the preparation and editing of the manuscript. SWRT undertook the literature review and gap analysis. The author(s) read and approved the final manuscript.

\section{Funding}

The Determining Volcanic Risk in Auckland (DEVORA) research programme and the New Zealand Earthquake Commission (EQC) provided funding for this project.

\section{Availability of data and materials} Not applicable.

Ethics approval and consent to participate Not applicable.

Consent for publication

Not applicable.

Competing interests

We declare we do not have any competing interests. 
Received: 19 December 2019 Accepted: 18 June 2020 Published online: 25 September 2020

\section{References}

Abersten $L$ (1984) Diversion of a lava flow from its natural bed to an artificial channel with the aid of explosives: Etna, 1983. Bull Volcanol 47(4):1165-1177. https://doi.org/10.1007/BF01952370

Adamczyk E (2014) Volcanic lava damages second Cape Verde town. United Press International

Allard P, Baxter P, Halbwachs M, Kasareka M, Komorowski JC, Joron JL (2003) The most destructive effusive eruption in modern history: Nyiragongo (RD. Congo) EGS - AGU - EUG Joint Assembly, Nice, April 2003

Al Bawaba A (2015) Ecowas gives cape Verde US300, 000 in support of volcanic eruption victims. Amman: SydniGate Media.

Ambeh WB, Fairhead JD, Francis DJ, Nnange JM, Soba D (1989) Seismicity of the Mount Cameroon region, West Africa. J Afr Earth Sci 9:1-7

Andronico D, Branca S, Calvari S, Burton M, Caltabiano T, Corsaro RA, Del Carlo P, Garfi G, Lodato L, Miraglia L, Mure F, Neri M, Pecora E, Pompilio M, Salerno G, Spampinato $L$ (2005) A multi-disciplinary study of the 2002-03 Etna eruption: insights into a complex plumbing system. Bull Volcanol 67:314-330. https:// doi.org/10.1007/s00445-004-0372-8

Aramaki S, Hayakawa Y, Fuji T, Nakamura K, Fukuoka T (1986) The October 1983 eruption of Miyakejima volcano. J Volcanol Geotherm Res 29:203-229

Ateba B, Dorbath C, Dorbath L, Ntepe N, Frogneux M, Aka FT, Hell JV, Delmond JC, Manguelle D (2009) Eruptive and earthquake activities related to the 2000 eruption of Mount Cameroon volcano (West Africa). J Volcanol Geotherm Res 179:206-216. https://doi.org/10.1016/j.jvolgeores.2008.11.021

Ateba B, Ntepe N (1997) Post-eruptive seismic activity of Mount Cameroon (Cameroon, West Africa): a statistical analysis. J Volcanol Geotherm Res 79: 25-45

Avolio MV, Crisci GM, Di Gregorio S, Rongo R, Spataro W, Trunfio GA (2006) SCIA RA y2: an improved cellular automata model for lava flows and applications to the 2002 Etnean crisis. Comput Geosci 32:876-889. https://doi.org/10. 1016/j.cageo.2005.10.026

Bachelery P, Lenat J, Di Muro A, Michon L (eds), Active volcanoes of the southwest Indian Ocean. Berlin: Springer-Verlag.

Barberi F, Brondi F, Carapezza ML, Cavarra L, Murgia C (2003) Earthen barriers to control lava flows in the 2001 eruption of Mt. Etna. J Volcanol Geotherm Res 123:231-243. https://doi.org/10.1016/S0377-0273(03)00038-6

Barberi F, Carapezza ML, Valenza M, Villari L (1992) L'eruzione 1991-1992 dell'Etna e gli interventi er fermare o ritardare l'avanzata della lava

Barberi F, Carapezza ML, Valenza M, Villari L (1993) The control of lava flow during the 1991-1992 eruption of Mt.Etna. J Volcanol Geotherm Res 56:1-34

Behncke B, Neri M (2003) Cycles and trends in the recent eruptive behaviour of Mount Etna (Italy). Can J Earth Sci 40:1405-1411. https://doi.org/10.1139/E03-052

Bird DK, Gisladottir G, Dominey-Howes D (2011) Different communities, different perspectives: issues affecting residents' response to a volcanic eruption in southern Iceland. Bull Volcanol 73:1209-1227. https://doi.org/10.1007/s00445011-0464-1

Black J (2019) Lower east rift zone after action review. Hawaii County. Internal report, Hilo

Blake DM, Wilson G, Stewart C, Craig HM, Hayes JL, Jenkins SF, Wilson TM Horwell CJ, Andreastuti S, Daniswara R, Ferdiwijaya D, Leonard GS, Hendrasto M, Cronin S (2015) The 2014 eruption of Kelud volcano, Indonesia: impacts on infrastructure, utilities, agriculture, and health. GNS Science Report 2015/15, p 144

Blong RJ (1984) Volcanic hazards: a sourcebook on the effects of eruptions. Academic Press, Sydney, p 424

Bompard P, Philips J (1992) The Times 1992 April

Bonaccorso A, Calvari S, Boschi E (2016) Hazard mitigation and crisis management during major flank eruptions at Etna volcano: reporting on real experience. Sicily. https://doi.org/10.1144/SP426.4

Bonaccorso A, Neri M, Tomarchio G (2003) Eruzione Perfetta Lunga [film]. Graphofilm Production

Bonne K, Kervyn M, Cascone L, Njome S, Van Ranst E, Suh E et al (2008) A new approach to assess long-term lava flow hazard and risk using GIS and lowcost remote sensing: the case of Mount Cameroon, West Africa. Int J Remote Sens 29:6539-6564. https://doi.org/10.1080/01431160802167873

Branca S, Azzaro R, De Beni E, Chester D, Duncan A (2015) Impacts of the 1669 eruption and the 1693 earthquakes on the Etna region (eastern Sicily, Italy): an example of recovery and response of a small area to extreme events. J
Volcanol Geotherm Res 303:25-40. https://doi.org/10.1016/j.jvolgeores.2015. 07.020

Branca S, De Beni E, Chester D, Duncan A, Lotteri A (2017) The 1928 eruption of Mt Etna (Italy): reconstructing lava flow evolution and the destruction and recovery of the town of Mascali. J Volcanol Geotherm Res. https://doi.org/10. 1016/j.jvolgeores.2017.02.002

Branca S, Del Carlo P (2005) Types of eruptions at Etna volcano AD 1670-2003: implications for short-term eruptive behaviour. Bull Volcanol 67:732-742. https://doi.org/10.1007/s00445-005-0412-z

Brantley SR, Kauahikaua JP, Babb JL, Orr TR, Patrick MR, Poland MP et al (2019) Communication strategy of the U.S. Geological Survey Hawaiian volcano observatory during the lava-flow crisis of 2014-2015, Killauea volcano, Hawai'i. In: Poland MP, Garcia MO, Camp VE, Grunder A (eds) Field volcanology: a tribute to the distinguished career of Don Swanson. Geological Society of America, Boulder. https://doi.org/10.1130/2018.2538(16)

Callis T, Brestovansky M (2018) Bigger belch at summit : residents given masks to protect against ash. Hilo: Hawaii Tribune Herald

Calvari S, Coltelli M, Neri M, Pompilio M, Scribano V (1994) The 1991-1993 Etna eruption: chronology and lava flow-field evolution. Acta Volcanol 4:1-14

Cappello A, Ganci G, Calvari S, Perez NM, Hernandez PA, Silva SV, Cabral J, Del Negro C (2016) Lava flow hazard modeling during the 2014-2015 Fogo eruption, Cape Verde. J Geophys Res Solid Earth 121:2290-2303. https://doi. org/10.1002/2015JB012666. Received

Cappello A, Geshi N, Neri M, Del Negro C (2015) Lava flow hazards- an impending threat at Miyakejima volcano, Japan. J Volcanol Geotherm Res 308:1-9. https://doi.org/10.1016/j.jvolgeores.2015.10.005

Cappello A, Vicari A, Del Negro C (2011) Assessment and modeling of lava flow hazard on Mt. Etna volcano Boll di Geofis Teor ed Appl 52:299-308. https:// doi.org/10.4430/bgta0003

Carapezza M (2017) Molti fuochi ardono sotto il suolo de terremoti, volcani e statue. Sellerio, Palmero, p 310

CDEM (2015) Auckland volcanic field contingency plan. Auckland: Auckland Emergency Management

Chester DK, Degg M, Duncan AM, Guest JE (2001) The increasing exposure of cities to the effects of volcanic eruptions: a global survey. Environmental Hazards 2:89-103. https://doi.org/10.1016/S1464-2867(01)00004-3

Chester DK, Duncan AM, Sangster H (2012) Human responses to eruptions of Etna (Sicily) during the late-pre-industrial era and their implications for present-day disaster planning. J Volcanol Geotherm Res. https://doi.org/10. 1016/j.jvolgeores.2012.02.017

Ching A, Morrison L, Kelley M (2020) Intersecting with nature: tropical storms, lava flows and the resilience of island residents. Int J Disaster Risk Reduction 47:101546. https://doi.org/10.1016/j.ijdrr.2020.101546

Chirico GD, Favalli M, Papale P, Boschi E, Pareschi MT (2009) Lava flow Hazard at Nyiragongo volcano, D.R.C. 2. Hazard reduction in urban areas. Bull Volcanol 71:375-387. https://doi.org/10.1007/s00445-008-0232-z

Coltelli M, Marsella M, Proietti C, Scifoni S (2012) The case of the 1981 eruption of Mount Etna: an example of very fast moving lava flows. Geochem Geophys Geosystems 13(1). https://doi.org/10.1029/2011GC003876

Coltelli M, Proietti C, Branca S, Marsella M, Andronico D, Lodato L (2007) Analysis of the 2001 lava flow eruption of Mt. Etna from three-dimensional mapping J Geophys Res 112:1-18. https://doi.org/10.1029/2006JF000598

Cordonnier B, Lev E, Garel F (2016) Benchmarking lava-flow models. In: Harris AJL, De Groeve T, Garel F, Carn SA (eds) Detecting, Modelling, and responding to effusive eruptions. Geological Society of London, London

County of Hawai'i (2019) Kïlauea Eruption Recovery. https://recovery. hawaiicounty.gov/home-recovery. Accessed 25 Sept 2019

Crane C (2011) Into the volcano: scientists climb into a lava-filled crater to study one of the world's most dangerous volcanoes. New York: Science World

Crisci GM, Di Gregorio S, Rongo R, Scapelli M, Spataro W, Calvari S (2003) Revisiting the 1669 Etnean eruptive crisis using a cellular automata model and implications for volcanic hazard in the Catania area. J Volcanol Geotherm Res 123:211-230. https://doi.org/10.1016/S0377-0273(03)00037-4

D'Ambrosio D, Filippone G, Marocco D, Rongo R, Spataro W (2013) Efficient application of GPGPU for lava flow hazard mapping. J Supercomput 65:630644. https://doi.org/10.1007/s11227-013-0949-0

Davoine P, Saint-Marc C (2016) A geographical information system for mapping eruption risk at piton de la Fournaise. In: Bachelery $\mathrm{P}$, Lenat J, Di Muro A, Michon $L$ (eds) Active volcanoes of the Southwest Indian Ocean. Springer-Verlag, Berlin

Deligne NI (2012) After the flow: landscape response to the emplacement of Holocene lava flows, Central Oregon cascades, USA. University of Oregon, Dissertation 
Deruelle B, Bardintzeff J, Cheminee J, Ngounouno I, Lisson J, Nkoumbou C, Etame J, Hell J, Tanyileke G, N'ni J, Ateba B, Ntepe N, Nono A, Wadji P, Fosso J, Nkouathio DG (2000) Eruptions simultanees de basalte alcalin ed de hawaiite au mont Cameroun (28 mars-17 avril 1999). Geomateriaux 331:525-531

Deruelle B, N'ni J, Kambou R (1987) Mount Cameroon: an active volcano of the Cameroon line. J African Earth Sci 6:197-214. https://doi.org/10.1016/08995362(87)90061-3

Devries $\mathrm{H}$ (n.d.) New spurt from Mt. Etna threatens market town, Christian Science Monitor. Boston.

Dietterich HR, Lev E, Chen J, Richardson JA, Cashman KV (2017) Benchmarking computational fluid dynamics models of lava flow simulation for hazard assessment, forecasting, and risk management. J Appl Volcanol 6. https://doi. org/10.1186/s13617-017-0061-x

Dietterich HR, Patrick MR, Diefenbach AK, Parcheta CE, Lev E, Foks NL, et al (2018) Lava flow hazard modeling and the assessment of effusion rates and topographic change with UAS and lidar during the 2018 Kilauea lower east rift zone eruption. AGU fall meeting, Washington D.C., December 2018

Dobran F, Macedonio G (1992) Lava modeling contributions of the volcanic simulation group during the 1991-1992 eruption of Mt. Etna, Giardini, Pisa, Italy. INGV, Rome

Durand M, Gordon K, Johnston D, Lorden R, Poirot T, Scott J, Shephard B (2001) Impacts of, and responses to ashfall in Kagoshima from Sakurajima volcanolessons for New Zealand. GNS Science Report. 2001/30, p 67

Economist Intelligence Unit (2014) Cabo Verde economy: quick view—volcano eruptions on Fogo Island. The Economist

Fairhead JD (1985) Preliminary study of the seismicity associated with the Cameroon volcanic province during the eruption of Mt. Cameroon in 1982. J African Earth Sci 3(3):297-301. https://doi.org/10.1016/0899-5362(85)90003-X

Favalli M, Chirico GD, Papale P, Pareschi MT, Boschi E (2009a) Lava flow hazard at Nyiragongo volcano, D.R.C. 1. Model calibration and hazard mapping. Bull Volcanol 71:363-374. https://doi.org/10.1007/s00445-008-0233-y

Favalli M, Chirico GD, Papale P, Pareschi MT, Coltelli M, Lucana N, Boschi E (2006) Computer simulations of lava flow paths in the town of Goma, Nyiragongo volcano, Democratic Republic of Congo. J Geophys Res Solid Earth 111. https://doi.org/10.1029/2004JB003527

Favalli M, Pareschi MT, Neri A, Isola I (2005) Forecasting lava flow paths by a stochastic approach. Geophys Res Letters 32:L03305. https://doi.org/10.1029/ 2004GL021718

Favalli M, Tarquini S, Fornaciai A, Boschi E (2009b) A new approach to risk assessment of lava flow at Mount Etna. Geol Soc Am 37(2):1111-1114. https://doi.org/10.1130/G30187A.1

Favalli M, Tarquini S, Papale P, Fornaciai A, Boschi E (2012) Lava flow hazard and risk at Mt. Cameroon volcano. Bull Volcanol 74:423-439. https://doi.org/10. 1007/s00445-011-0540-6

Fearnly CJ, Bird DK, Haynes K, McGuire WJ, Jolly G (eds) (2018) Observing the volcano world. Springer Open, New York. https://doi.org/10.1007/978-3-319-44097-2

Fernandes R, Faria B (2015) C4G team (2015) FOGO-2014: monitoring the Fogo 2014 eruption, Cape Verde. EGU, Vienna

Finch RH, MacDonald GA (1953) Hawaiian volcanoes during 1950. Reston, VA: US Geological Survey. USGS Bulletin 996-B:65. https://doi.org/10.3133/b996B

Finkel M (2011) The volcano next door: scientists descend to a fiery lava lake to protect a Congolese city in its path. Washington DC: National Geographic Explorer

Fitton JG, Kilburn CRJ, Thirlwall MF, Hughes DJ (1983) 1982 eruption of Mount Cameroon, West Africa. Nature. 306:327-332

Frazzetta G, Romano R (1984) The 1983 Etna eruption: event chronology and morphological evolution of the lava flow. Bull Volcanol doi. https://doi.org/ 10.1007/BF01952364

Fujita S, Sakurai T, Matsuda K (2003) Wet and dry deposition of sulfur associated with the eruption of Miyakejima volcano, Japan. J Geophys Res: Atmospheres 108(D15). https://doi.org/10.1029/2002JD003064

Furuya M, Okubo S, Sun W, Tanaka Y, Oikawa J, Watanabe H, Maekawa T (2003) Spatiotemporal gravity changes at Miyakejima volcano, Japan: caldera collapse, explosive eruptions and magma movement. J Geotherm Res 108(B4). https://doi.org/10.1029/2002JB001989

Fuster-Casas JM (1971) Eruption produces lava fountains from three vents. In: La Palma (383010) in volcanoes of the world, v. 4.8.1. In Venzke, E. (ed.). Smithsonian Institution, Washington DC. https://doi.org/10.5479/si.GVP.VOTW4-2013

Gillot PY, Nativel P (1980) Eruptive history of the piton de la Fournaise volcano, Reunion Island, Indian Ocean. J Volcanol Geotherm Res 36(1-3):53-65. https://doi.org/10.1016/0377-0273(89)90005-X
Giordano D, Polacci M, Longo A, Papale P, Dingwell DB, Boschi E, Kasereka M (2007) Thermo-rheological magma control on the impact of highly fluid lava flows at Mt. Nyiragongo. Geophys Res Lett 34:2-5. https://doi.org/10.1029/ 2006GL028459

Global Volcanism Program (2019a) Cameroon (224010) in volcanoes of the World, v. 4.8.1. In Venzke, E. (ed.). Smithsonian Institution, Washington DC. https://doi.org/10.5479/si.GVP.VOTW4-2013

Global Volcanism Program (2019b) Fogo (384010) in volcanoes of the World, v. 4. 8.1. In Venzke, E. (ed.). Smithsonian Institution, Washington DC. https://doi. org/10.5479/si.GVP.VOTW4-2013

Global Volcanism Program (2019c) Izu-Oshima (284010) in volcanoes of the World, v. 4.8.1. In Venzke, E. (ed.). Smithsonian Institution, Washington DC. https://doi.org/10.5479/si.GVP.VOTW4-2013

Global Volcanism Program (2019d) Mauna Loa (332020) in volcanoes of the World, v. 4.8.1. In Venzke, E. (ed.). Smithsonian Institution, Washington DC. https://doi.org/10.5479/si.GVP.VOTW4-2013

Global Volcanism Program (2019e) Miyakejima (284040) in volcanoes of the World, v. 4.8.1. In Venzke, E. (ed.). Smithsonian Institution, Washington DC. https://doi.org/10.5479/si.GVP.VOTW4-2013

Global Volcanism Program (2019) Nyiragongo (223030) in Volcanoes of the World, v. 4.8.1. In Venzke, E. (ed.). Smithsonian Institution, Washington DC. https://doi.org/10.5479/si.GVP.VOTW4-2013

Global Volcanism Program (2019g) Piton de la Fournaise (233020) in Volcanoes of the World, v. 4.8.1. In Venzke, E. (ed.). Smithsonian Institution, Washington DC. https://doi.org/10.5479/si.GVP.VOTW4-2013

Guest JE, Underwood JR, Greeley R (1980) Role of lava tubes in flows from the observatory vent, 1971 eruption on Mount Etna. Geol Mag 117:601-606. https://doi.org/10.1017/S0016756800028946

Haapala I (2011) The Sahama's (1910-1983) volcanological and mineralogical studies in Africa: part ii. Minerals of granitic pegmatites and other mineral occurrences of eastern and southern Africa. Bull Geol Soc Finl 83:57-70

Harris A, Villeneuve N (2018a) Newspaper reporting of the April 2007 eruption of piton de la Fournaise part 1: useful information or tabloid sensationalism? J App Volcanol 7. https://doi.org/10.1186/s13617-018-0073-1

Harris A, Villeneuve N (2018b) Newspaper reporting of the April 2007 eruption of piton de la Fournaise, part 2: framing the hazard. J App Volcanol 7. https:// doi.org/10.1186/s13617-018-0072-2

Harris AJL (2015) Basaltic lava flow hazard. In: Shroder JF, Paple P (eds) Volcanic hazards, risks and disasters. Elsevier. https://doi.org/10.1016/B978-0-12396453-3.00002-2

Harris AJL, Carn S, Dehn J, Del Negro C, Gudmundsson MT, Cordonnier B, Barnie T, Chahi E, Calvari S, Catry T, de Groeve T, Coppola D, Davies A, Favalli M, Ferrucci F, Fujita E, Ganci G, Garel F, Huet P, Kauahikaua J, Kelfoun K, Lombardo V, Macedonio G, Pacheco J, Patrick M, Pergola N, Ramsey M, Rongo R, Sahy F, Smith K, Tarquini S, Thordarson T, Villeneuve N, Webly P, Wright R, Zaksek K (2016b) Conclusion: recommendations and finds of the RED SEED working group. In: Harris AJL, De Groeve T, Garel F, Carn SA (eds) Detecting, Modelling, and responding to effusive eruptions. Geological Society of London, London

Harris AJL, De Groeve T, Garel F, Carn SA (eds) (2016a) Detecting, Modelling, and responding to effusive eruptions. Geological Society of London, London

Harris AJL, Favalli M, Wright R, Garbeil H (2011) Hazard assessment at Mount Etna using a hybrid lava flow inundation model and satellite-based land classification. Nat Hazards 58:1011-1027. https:/doi.org/10.1007/s11069-010-9709-0

Hawai'i Electric Light (2014a) Hawai'i electric Light enacts lava flow plans. HELCO, Hilo

Hawai'i Electric Light (2014b) Hawai'i electric Light lava flow response update. HELCO, Hilo

Herbert D, Bardossi F (1968) Kilauea: case history of a volcano, 1st edn. Harper \& Row, Evanston, Illinois

Huntington AT (1972) The eruption of Mount Etna, 1971. Sci Prog 60:107-119

HVO (2016) VOLCANO WATCH: Mauna Loa 1950 eruption, a lot of lava with little warning. Big Island Now, Hilo

HVO (2018) Kïlauea 1955 lower east rift zone eruption in lower Puna. https:// volcanoesusgsgov/volcanoes/kilauea/geo_hist_1955html Accessed 14 Aug 2019

Ishihara K, Iguchi M, Kamo K (1989) Numerical simulation of lava flows on some volcanoes in Japan. Lava Flows and Domes. IAVCEI

Jenkins SF, Day SJ, Faria BVE, Fonseca JFBD (2017) Damage from lava flows: insights from the 2014-2015 eruption of Fogo. Cape Verde J App Volcanol 6. https://doi.org/10.1186/s13617-017-0057-6 
Jenkins SF, Spence RJS, Fonseca JFBD, Solidum RU, Wilson TM (2014) Volcanic risk assessment: quantifying physical vulnerability in the built environment. J Volcanol Geotherm Res 276:105-120. https://doi.org/10.1016/j.jvolgeores. 2014.03.002

Jennings JH (1959) The eruption of Mount Cameroon, February-march 1959. Geogr 44(3):207-208

Kauahikaua JP, Tilling RI (2014) natural hazards and risk reduction in Hawai'i. In: Poland MP, Takahashi TJ, Landowski CM (eds) Characteristics of Hawaiian volcanoes. US Geological Survey. U.S. Geological Survey Professional Paper, Reston, VA

Kilburn C (2015) Lava flow hazards and modelling. In: Sigurdsson H (ed) The encyclopedia of volcanoes, 2nd edn. Academic Press, San Diego. https://doi. org/10.1016/B978-0-12-385938-9.0055-9

Komorowski JC, Morin J, Jenkins S, Kelman I (2018) Challenges of volcanic crises on small islands states. In: Fearnley CJ, Bird DK, Haynes K, McGuire WJ, Jolly G (eds) Observing the volcano world. Springer, New York. https://doi.org/10. 1007/11157_2015_15

Krafft M (1982) L'éruption volcanique de Kartala en avril 1977 (Grande Comore, ocean Indien). CR Acad Sc Paris 294:753-758

Lacey M (2002a) Warily, residents return to lava-scarred Congo city. New York Times, New York

Lacey M (2002b) Volcano-scorched Congo city, ground shaking, returns to a nervous kind of normal. New York Times, New York

Latutrie B, Andredakis I, de Grove T, AJL H, Langlois E, van Wyk de Vries B, Saubin E, Bilotta G, Cappello A, Crisci GM, D'Ambrosio D, del Negro C, Favalli M, Fujita E, lovine G, Kelfoun K, Rongo R, Spataro W, Tarquini S, Coppola D, Ganci G, Marchese F, Pergola N, Tarmutoli V (2016) Testing a geographical information system for damage and evacuation assessment during an effusive volcanic crisis. In: AJL H, De Groeve T, Garel F, Carn SA (eds) (2016a)Detecting, Modelling, and responding to effusive eruptions. Geological Society of London, London

Lenat J (2016) A brief history of the observation of the central area of piton de la Fournaise. In: Bachelery P, Lenat J, Di Muro A, Michon L (eds) Active volcanoes of the Southwest Indian Ocean. Springer-Verlag, Berlin. https://doi. org/10.1007/978-3-642-31395-0

MacDonald GA (1954) Activity of Hawaiian volcanoes during the years 1940-1950. Bull Volcanol 15:119-179. https://doi.org/10.1007/BF02596001

Macdonald GA (1958) Barriers to protect Hilo from lava flows. Pacific Sci 12:258-277

Macdonald GA (1962) The 1959 and 1960 eruptions of Kilauea volcano, Hawaii, and the construction of walls to restrict the spread of the lava flows. Bull Volcanol 24:249-294. https://doi.org/10.1007/BF02599351

Macdonald GA (1975) Volcanic Hazards. In: Geological Hazards. Springer, New York

Maugeri M, Romano R (1981) Suggestions for preventative and/or defensive works against lava flows in the Etnean area. Bull BRGM 4(2):179-185

Mcmullen C (2015) County of Hawaii to reopen transfer station shuttered by lava flow. Pahoa, Hawaii: Waste360

Ministry of Foreign Affairs of Japan (2014) Emergency assistance to Cabo Verde in response to the eruption of Pico de Fogo volcano. States News Service

Miyamoto H, Sasaki S (1997) Simulating lava flows by an improved cellular automata method. Comput Geosci 23:283-292. https://doi.org/10.1016/ S0098-3004(96)00089-1

Morin J, Lavigne F (2009) Institutional and social responses to hazards related to Karthala volcano, Comoros. Int J Res Island Cultures 3(1):54-71

Morin J, Lavigne F, Bachelery P, Finzola A, Villeneuve N (2009) Institutional and social responses to hazards related to Katahala volcano, Comoros part 1: analysis of the may 2006 eruptive crisis. Int J Res Island Cultures 3(1):33-53

Morrison AA, Whittington AG, Smets B, Kervyn M, Sehlke A (2020) The rheology of crystallising basaltic lavas from Nyiragongo and Nyamuragira volcanoes, D. R.C. Volcanica. 3(1):1-28. https://doi.org/10.30909/vol.03.01.0128

Mossoux S, Delcamp A, Poppe S, Michellier C, Canters F, Kervyn M (2016) Hazagora: will you survive the next disaster? - a serious game to raise awareness about geohazards and disaster risk reduction. Nat Hazards Earth Syst Sci 16:135-147. https://doi.org/10.5194/nhess-16-135-2016

Mossoux S, Kervyn M, Canters F (2019) Assessing the impact of road segment obstruction on accessibility of critical services in case of a hazard. Nat Hazards Earth Syst Sci 19:1251-1263. https://doi.org/10.5194/nhess-19-1251-2019

Nairn IA, Scott BJ (1995) Scientific management of the 1994 Rabaul eruption: lessons for New Zealand GNS Science Report 95/26, p 45

Nave R, Ricci T, Pacilli MG (2016) Perception of risk for volcanic hazard in Indian Ocean: La Reunion Island case study. In: Bachelery P, Lenat J, Di Muro A,
Michon L (eds) Active volcanoes of the Southwest Indian Ocean. SpringerVerlag, Berlin. https://doi.org/10.1007/978-3-642-31395-0

Neal CA, Brantley SR, Antolik L, Babb JL, Burgess M, Calles K et al (2019) The 2018 rift eruption and summit collapse of Kïlauea volcano. Science 363:367-374. https://doi.org/10.1126/science.aav7046

New Scientist (2002) Caught out again: the Goma volcano gave us a warning but no one was listening. New Scientist

Njome M, Suh C, Sparks RSJ, Ayonghe SN, Fitton JG (2008) The Mount Cameroon 1959 compound lava flow field: morphology, petrography and geochemistry. Swiss J Geosci 101:85-98. https://doi.org/10.1007/s00015-007-1245-x

Oppenheimer C (2011) Eruptions that shook the world. Cambridge University Press, Melbourne

Orr TR, Poland MP, Patrick MR, Thelen WA, Sutton AJ, Elias T, Thornber CR, Parcheta C, Wooten KM (2015) Kilauea's 5-9 march 2011 Kamoamoa fissure eruption and its relation to 30+ years of activity from Pu'u'O'Ōö. In: Carey R, Cayol V, Poland M, Weis D (eds) Hawaiian volcanoes: from source to surface. American Geophysical Union, Washington DC. https://doi.org/10.1002/ 9781118872079.ch18

Poland M, Orr TR, Kauahikaua JP, Brantley SR, Babb JL, Patrick MR, Neal CA, Anderson KR, Antolik L, Burgess M, Elias T, Fuke S, Fukunaga P, Johanson IA, Kagimoto M, Kamibayashi K, Lee L, Miklius A, Milion W, Moniz C, Okubo PG, Sutton AJ, Takahashi TJ, Thelen WA, Tollett W, Trusdell FA (2015) The 20142015 Pahoa lava flow crisis at Kilauea volcano, Hawai'il: disaster avoided and lessons learned. GSA Today 26:4-10. https://doi.org/10.1130/GSATG262A.1.4

Reuters (2001) Mount Etna's lava flow causes Italian officials to close a tourist refuge. New York Times, New York

Richter N, Favalli M, de Zeeuw-van Dalfsen E, Fornaciai A, da Silva Fernandes RM, Rodriquez NP, Levy J, Victoria SS, Walter TR (2016) Lava flow hazard at Fogo volcano, Cape Verde, before and after the 2014-2015 eruption. Nat Haz Earth Syst Discuss 16:1925-1951. https://doi.org/10.5194/nhess-16-1925-2016

Rongo R, Lupiano V, Spataro W, D'ambrosio D, lovine G, Crisci GM (2016) SCIARA: cellular automata lava flow modelling and applications in hazard prediction and mitigation. In: Harris AJL, De Groeve T, Garel F, Carn SA (eds) Detecting, Modelling, and responding to effusive eruptions. Geological Society of London, London

Sawada Y (1986) Miyake-Zima. In: annual report of the world volcanic eruptions in 1983. Bull Volcanol 26:1-73. https://doi.org/10.1007/BF01201906

Sawada Y, Aramaki S (1989) O-Shima. In: annual report of the world volcanic eruptions in 1986. Bull Volcanol 23:7-51. https://doi.org/10.1007/BF01197478

Schanche DA (1983) Risky experiment in Sicily: taming Mt. New Route for Fiery Flow. Los Angeles Los Angeles Times, Etna

Science News (1981) Major lava flow at Mt. Science News, Etna

Scifoni S, Coltelli M, Marsella M, Proietti C, Napoleoni Q, Vicari A, Del Negro C (2010) Mitigation of lava flow invasion hazard through optimized barrier configuration aided by numerical simulation: the case of the 2001 Etna eruption. J Volcanol Getherm Res 192:16-26. https://doi.org/10.1016/j. jvolgeores.2010.02.002

Shimozuru D, Osada N, Horigome K, Sawada M, Okada A, Shibano M, Matsumoto S, Sasaki K, Hosoya Y (1972) Volcanic and seismic characteristics of Izu islands - brief summary of the special project of prediction of volcanic eruptions. Bull Volcanol Soc Japan 17:66-87

Smithsonian Institution's Global Volcanism Network (1995) Summary of recent volcanic activity. Bull Volcanol 57:371-375. https://doi.org/10.1007/BF00301294

Staudacher T, Peltier A, Ferrazzini V, Di Muro A, Boissier P, Catherine P, Kowalski P, Lauret F, Lebreton J (2016) Fifteen years of intense eruptive activity (19982013) at piton de la Fournaise volcano: a review. In: Bachelery P, Lenat J, Di Muro A, Michon L (eds) Active volcanoes of the Southwest Indian Ocean. Springer-Verlag, Berlin. https://doi.org/10.1007/978-3-642-31395-0

Stewart CM (2014) Mankind versus nature. West Hawaii Today, Kailua Kona

Suh CE, Sparks RSJ, Fitton JG, Ayonghe SN, Annen C, Nana R, Luckman A (2003) The 1999 and 2000 eruptions of Mount Cameroon: eruption behaviour and petrochemistry of lava. Bull Volcanol 65:267-281. https://doi.org/10.1007/ s00445-002-0257-7

Suh CE, Stansfield SA, Sparks RSJ, Njome MS, Wantim MN, Ernst GGJ (2011) Morphology and structure of the 1999 lava flows at Mount Cameroon volcano (West Africa) and their bearing on the emplacement dynamics of volume-limited flows. Geol Mag 148:22-34. https://doi.org/10.1017/ S0016756810000312

Sumner JM (1998) Formation of clastogenic lava flows during fissure eruption and scoria cone collapse: the 1986 eruption of Izu-Oshima volcano, eastern Japan. Bull Volcanol 60:195-212. https://doi.org/10.1007/s004450050227 
Sword-Daniels V, Wardman J, Stewart C, Wilson T, Johnson D, Rossetto T (2011) Infrastructure impacts, management and adaptions to eruptions at Volcan Tungurahua, Ecuador, 1999-2010. GNS Science Report. 2011/24, p 76

Tarquini S, Favalli (2010) Changes to the susceptibility to lava flow invasion induced by morphological modifications of an active volcano: the case of Mount Etna, Italy. Nat Hazards 54: 537-546. doi: https://doi.org/10.1007/ S11069-009-9484-y

Tarquini S, Favalli M (2016) Simulating the area covered by lava flows using the DOWNFLOW code. In: Harris AJL, De Groeve T, Garel F, Carn SA (eds) Detecting, Modelling, and responding to effusive eruptions. Geological Society of London, London

Tarr JA (1984) The evolution of the urban infrastructure in the 19th and 20th centuries. In: Perspectives on urban infrastructure. The National Academies Press, Washington DC. https://doi.org/10.17226/561

Tazieff H (1977) An exceptional eruption: Mt. Nyiragongo, Jan. 10th, 1977. Bull. Volcanol 40:189-200. https://doi.org/10.1007/BF02596999

Tazieff H (1985) RECENT ACTIVITY AT NYIRAGONGO AND LAVA-LAKE OCCURRENCES. Geol Soc Finl 57:11-19

Thorarinsson S, Steinthorsson S, Einarsson T, Kristmannsdottir H, Oskarsson N (1973) The eruption on Heimaey, Iceland. Nature 241:372-375. https://doi. org/10.1038/241372a0

Tomarchio G (n.d.) La Trasparenza (movie). RAl, Rome

Tsang SWR, Lindsay JM (in prep) Lava flow crises in inhabited areas part 2: case studies of Kilauea (USA) and Etna (Italy) and future directions for lava flow documentation. J App Volcanol

Tsang SWR, Lindsay JM, Coco G, Wysocki R, Lerner GA, Rader E, Turner GM, Kennedy B (2019a) The heating of substrates beneath basaltic lava flows. Bull Volcanol 81. https://doi.org/10.1007/s00445-019-1320-y

Tsukui M, Kawanabe Y, Niihori K (2005) Geological map of Miyakejima volcano. Bull Earthq Res Inst, Tokyo

Turner NR, Perroy RL, Hon K (2017) Lava flow hazard prediction and monitoring with UAS: a case study from the 2014-2015 Pāhoa lava flow crisis, Hawai'i. J App Volcanol 6:17. https://doi.org/10.1186/s13617-017-0067-3

United Nations Office for Disaster Risk Reduction- Regional Office for Africa (2014) Fogo volcano forces more evacuations. States News Services

United Nations Regional Information Networks (2002a) Victims of volcano stream back home. Africa News Service

Walker GPL (1973) Lengths of lava flows. Phil Trans R Soc Lond A 274:107-118

Wantim MN, Kervyn M, Ernst GGJ, del Marmol MA, Suh CE, Jacobs P (2013)

Numerical experiments on the dynamics of channelized lava flows at Mount Cameroon volcano with the FLOWGO thermo-rheological model. J Volcanol Geotherm Res 253:35-53. https://doi.org/10.1016/j.jvolgeores.2012.12.003

Watts D (1986) Thousands flee island volcano eruption; Izu Oshima island, Japan. The Times, London

Williams RS, Moore JG (1983) Man against volcano: the eruption on Heimaey, Vestmennaeyjar, Iceland. Rep. USGS Unnumbered Ser Gen Interes Publ, p 26

Wilson G, Wilson TM, Deligne NI, Blake DM, Cole JW (2017) Framework for developing volcanic fragility and vulnerability functions for critical infrastructure. J App Volcanol 6. https://doi.org/10.1186/s13617-017-0065-6

Wilson G, Wilson TM, Deligne NI, Cole JW (2014) Volcanic hazard impacts to critical infrastructure: a review. J Volcanol Geotherm Res 286:148-182. https://doi.org/10.1016/j.jvolgeores.2014.08.030

Worsley P (2015) Physical geology of the Fogo volcano (Cape Verde Islands) and its 2014-2015 eruption. Geol Today 31:153-159. https://doi.org/10.1111/gto.12102

WOVO (n.d.) Observatorio Vulcanologico de Cabo Verde (OVCV). http://wwwwovoorg/1808html Accessed 10 Dec 2019

Wright TL, Chun JYF, Exposo J, Heliker C, Hodge J, Lockwood JP, Vogt SM (1992) Map showing lava-flow hazard zones, island of Hawaii. U.S. Geological Survey, Reston (VA)

\section{Publisher's Note}

Springer Nature remains neutral with regard to jurisdictional claims in published maps and institutional affiliations.

Ready to submit your research? Choose BMC and benefit from:

- fast, convenient online submission

- thorough peer review by experienced researchers in your field

- rapid publication on acceptance

- support for research data, including large and complex data types

- gold Open Access which fosters wider collaboration and increased citations

- maximum visibility for your research: over $100 \mathrm{M}$ website views per year

At BMC, research is always in progress.

Learn more biomedcentral.com/submissions 